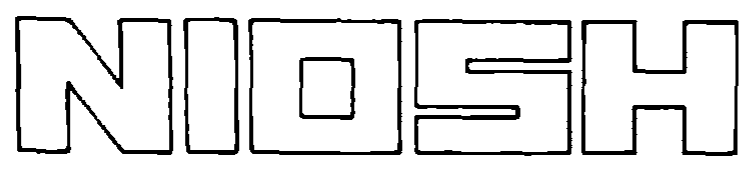

\title{
Preventing Health Hazards from Exposure to Benzidine Congener Dyes
}

U.S. DEPARTMENT OF HEALTH AND HUMAN SERVICES

Public Health Service

Centers for Disease Control

National Institute for Occupational Safety and Health 
PREVENTING HEALTH HAZARDS FROM EXPOSURE TO BENZIDINE CONGENER DYES

\section{U.S. DEPARTMENT OF HEALTH AND HUMAN SERVICES Public Health Service Centers for Disease Control}

National Institute for Occupational Safety and Health

January 1983 


\section{DISCLAIMER}

\section{Mention of company names or products does not constitute endorsement}

by the National Institute for Occupational Safety and Health

DHHS (NIOSH) Publication No. 83-105 
Exposures to benzidine congener dyes in the workplace may increase the risk of cancer in the exposed workers. In particular, dyes based on the chemical benzidine may be carcinogenic; dyes based on o-tolidine or o-dianisidine may also pose a carcinogenic risk to workers. Cancer could be caused by the dye itself, by leftover parent chemicals and impurities in the dye after its manufacture, or by chemicals resulting from breakdown of the dye in the body. The risk of cancer extends beyond the manufacture of benzidine congener dye where there is potential exposure to benzidine (a known carcinogen), o-tolidine, or o-dianisidine (suspected carcinogens). Workers who use the dye or the dyed product may also be at risk and should be well protected.

The National Institute for Occupational Safety and Health (NIOSH) has developed this publication to alert supervisors, workers, safety committees, and safety directors to these hazards as well as to suggest the necessary protective measures. To aid in determining whether or not benzidine congener dyes are being used in a particular setting, Appendix A lista many of their tradenames and synonyms, grouped by their parent chemical.

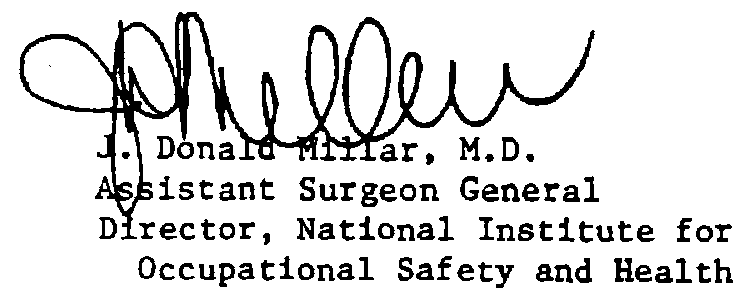




$\begin{array}{lr}\text { PREFACE } & \text { Page } \\ \text { BACKGROUND } & \text { iii } \\ & 1 \\ \text { QUESTIONS OFTEN ASKED ABOUT BENZIDINE CONGENER DYES } & 2 \\ \text { Sources of Exposure/Who Is Exposed } & 2 \\ \text { Reduction of Exposure } & 4 \\ \text { Personal Protective Equipment } & 6 \\ \text { Health Effects/Medical and Environmental Evaluation } & 9 \\ \text { APPENDIX A - BCD Tradenames and Generic Names, By Parent Chemical } & 11 \\ \text { Benzidine-Based Dyes } & 12 \\ \text { o-Tolidine-Based Dyes } & 30 \\ \text { O-Dianisidine-Based Dyes } & 35 \\ & 43\end{array}$




\section{BACKGROUND}

In this publication, the term benzidine congener dyes (BCDB) refers to commercial preparations of those dyes produced from either benzidine, or tho-tolidine, or orthodianisidine. The term "congener" (Latin for "same family") refers to their similarities in chemical structure.

Like many other technical grade dye formulations, each commercial benzidine congener dye may contain several chemicals. At least four of these chemicals--leftover parent compound (the so-called "chemical intermediate"), certain impurities, breakdown products, and the dye itself--may pose serious health hazards to workers.

Approximately 82 benzidine congener dyes are now or have been widely used in the U.S. They are marketed under several hundred tradenames (many are listed in Appendix $A$ of this publication). Although each of these 82 dyes has not been specifically tested for health effects, they have several important similarities. These similarities have led scientists at the National Institute for Occupational Safety and Health (NIOSH) to conclude, after extensive review of the data, that exposure to any of them in the workplace may increase the risk of cancer to exposed workers.

The conclusions reached by these scientists were based on the following findings:

1. Those dyes tested showed
2. Leftover parent chemicals in commercial preparations of these dyes are either known (benzidine) or suspected (o-tolidine, o-dianisidine) carcinogens.

3. Benzidine congener dye products are not pure, and may contain actual or potential carcinogens other than the dyes and their parent compounds. Impurities may have been present at the time of manufacture, or could have been formed as a result of dye breakdown during storage, especially if the dye had been exposed to heat.

4. Those BCDs tested were converted to the parent chemical in the bodies of several species of test animals. Available evidence supports biotransformation in humans of benzidine-based dyes to the parent compound, benzidine. Although less conclusive at this time, there is also evidence that humans metabolize o-tolidinebased dyes to their parent chemicals.

5. Members of this family of dyes, the benzidine congeners, have closely related chemical structures.

Earlier, when only the parent compound or other chemical precursors were thought to be hazardous, attention was focused on dye manufacturing workers. However, as a result of tests performed by the National Cancer Institute, it is now believed that the dyes themselves are potential carcinogens. 
of the entire range of chemicals tested to date in the National Cancer Institute's bioassay program, three benzidine-based dyes demonstrated the shortest "time-totumor" interval. These results suggested that the benzidine-based dyes themselves might be very potent carcinogens. Because the dyes themselves-not simply leftover intermediates, breakdown products, or contaminants--may be carcinogenic, it is not enough to protect against exposure to the dyes only during dye manufacture. Workers who apply the dye and workers who process the dye are also exposed to $a$ health hazard and must also be well protected.

Dye house workers are probably the most significantly exposed workers. Much less is known about the potential dye exposure of workers processing BCD-dyed fabrics, leather, and paper after these materials leave the dyeing plant. Generation of particulates from the BCD-dyed materials might occur, for example, in cutting, sewing, knitting, weaving, and finishing operations.

Although dye exposure in these processing operations is not well characterized, we do know that dyed particulates are generated when fabrics are prepared from dyed fibers, and that dyed particulates are released during cutting and sewing operations.

Because the posaibility of dye exposure during processing activities exists, but exposure data are at present not available, a determination of whether such workers face any health hazard from working with BCD-dyed materials must await further investigation.
In summary, several benzidine congener dyestuff constituents-the dye itself, leftover parent compound, breakdown products, and certain impurities--may present serious health hazards.

For the reasons discussed above, NIOSH recommends that worker exposure to benzidine-based dyes be reduced to the lowest level feasible, preferably by substituting safer dyes for benzidine-based dyes.

The available data on dyes based on o-tolidine and o-dianisidine, while less extensive and definitive than those for benzidine-based dyes, suggest that these dyes, and certain dye contaminants (including breakdown products occurring during storage or heating), may also present a cancer risk to workers. Exposure to these two additional classes of dyes should therefore be minimized. NIOSH recommends, as a prudent public health measure, that substitution of less toxic dyes be used as a control measure wherever possible.

QUESTIONS OFTEN ASKED ABOUT BENZIDINE CONGENER DYES

\section{SOURCES OF EXPOSURE/} WHO IS EXPOSED

Q: What are the most common industrial sources of exposure to benzidine congener dyes (BCDs)?

A: Exposure to BCDs is especially likely during various manufacturing operations:

Synthesis 
Processing (especially spray

drying, presscake drying,

milling, pulverizing, and

blending)

Packaging

Transportation

Maintenance and cleanup.

Exposure can also occur during kinds of dyeing procedures:

Textile dyeing

Pulp and paper dyeing

Lesther and fur dyeing.

Examples of these exposure situations include dye weighing and mixing; transfer to dyeing vats or paper beaters; leather spraying; maintenance and cleanup work; handling of dyed fabric, paper, fur, or leather; stripping of imperfectly dyed materials; and waste treatment and disposal operations.

Other applications in which BCD exposure may take place include the manufacture of:

Water-based inks

Wood stains

Plastics

Pigments

Hair dyes

Typewriter ribbons

Printed textiles

Soaps

Consumer dyeing products

Wood flours uaed as

resin fillers

Biological atains and

indicators.

The use of BCDs may have been discontinued in some of the above applications.

Still other potential exposure situations occur outside of manu- facturing and dyeing settings where particulates may be generated.

This work involves dyed textiles, leather, or paper in the following processing operations:

Finishing

Cutting

Sewing

Knitting or weaving with dyed fibers.

It is not known whether workers who are exposed to the dusts of BCD-dyed textiles or leather, such $a$ in cutting or bewing operations, face risks similar to $B C D$ workers in manufacturing and applications industries. The measurements needed to determine the nature and level of exposure to such dyed dusts have not yet been made.

Q: Are only production workers exposed?

A: No. Production workers are often the most routinely exposed workers; but maintenance and cleanup crews can also be aignificantly exposed. Such workers risk exposure when local exhaust ductwork requires cleaning, spills must be cleaned up, or process equipment must be disassembled. These individuala are of particular concern because some of the most effective exposure controlo available to production staff, such as process enclosure and local exhaust ventilation, are often the least likely to be available to maintenance workers.

Q: How does a person find out whether benzidine congener dyes are 
being used (or have been used) in a particular workplace?

A: Over 2,900 BCD tradenames are listed alphabetically in the back of this publication by major dye group (benzidine-based, otolidine-based, and o-dianisidinebased). Generic (common) names, such as Direct Black 38 , are included where known as an aid to dye identification. Posting this list at those work stations where exposure occurs would assist workers in determining whether they are being or have been exposed to BCDs.

Q: Where may substitutes for benzidine congener dyes be purchased?

A: Many companies can supply substitute dyes upon request. Substitutes may also be found by referring to the "Buyers Guide" published every July by the American Association of Textile Colorista and Chemists. The "Buyers Guide" can be ordered from:

The American Association of Textile Coloriats and Chemiats

Box 12215

Research Triangle Park

North Carolina 27709

\section{REDUCTION OF EXPOSURE}

Q: How do dyes enter the body?

A: There are three ways that dyes can enter the body. Dyes can be inhaled, swallowed, or contact the skin or eyes.

Breathing dye dusts and mists a1lows smaller particles to enter the lungs, where they may become trapped, be retained, or be ultimately degraded. Larger particles are either trapped by the mucous lining of the respiratory passages or are exhaled; those that are trapped are coughed up and may be swallowed. Eating, chewing, or smoking items contaminated with dye dusts, liquids, or pastes also allows dye to enter the body. Dye that is thus swallowed can be absorbed into the blood from the intestines, and can be transformed to the intermediate (parent compound) by bacteria living in the gut. Finally, some dye components may enter "the body by absorption through healthy or damaged skin, or through contact with the eyes.

Q: If the air doesn't look dusty, is it safe to breathe?

A: Not necessarily. The particles most likely to lodge in the lungs are too small to be seen by the naked eye.

Such particles are extremely light, and tend to float in the air before settling slowly to the ground or other surfaces. Just because the visible part of a dust cloud has settled doesn't mean the air is safe to breathe.

The only sure way to find out whether the-air in the worker's breathing zone is safe is to collect a sample of it with a personal sampler. The sample should then be analyzed by a certified industrial hygiene laboratory. Under the current medical and exposure records access standard, workers and their representatives have a legal right to see the results of workplace air sampling tests performed by or for their employers. 
Q: How can the risks to workers handling BCDs be most effectively minimized?

A: Replacement of BCDs with known safe dyes is the most effective means of reducing exposure. When substitution isn't a viable option, however, BCD exposure should be reduced to the lowest feasible level.

Although the amount of exposure that the body can safely tolerate is unknown, it is generally agreed that the smaller the exposure, the less the chance for developing an exposure-related disease. However, it is also possible that the chance of the disease developing will remain the same, but that at lower exposure levels it will take more time for the disease to develop.

One very effective method for reducing inhalation exposure involves changing the form in wich the dye is handled. For example, dyes can be supplied in paste, 1 iquid, or pelletized forms, or in soluble bags. Note that handing dyes in these forms does not necessarily reduce the need for effective protection against skin exposure (discusaed below).

Inhalation (as well as skin exposure) can be further reduced, often substantially, by preventing dyes from contaminating workplace air and work gurfaces (floors, benches, machinery, etc.). A particularly effective control method involves containing those operations where dye is transferred, weighed, mixed, metered, sampled, packaged, or otherwise handled. The technical term for this technique is process enclosure.

For example, enclooures (transparent types if visibility is important) may be attached to presscake grinders and to milling, bagging and drumming machines to contain dye particles. Local exhaust ventilation is frequently applied to such enclosures to make bure that any openings permitting leakage will cause air to flow into the encloaed area rather than out of it. Another example of process enclosure involves the use of liquid metering devices or gravity feeds for charging operations. By eliminating pouring and measuring steps, these devices can significantly reduce exposure due to $\mathrm{spills.}$

Where process enclosure is not practical, concentrations of airborne dyes can still be oubstantially reduced by local exhaust devices, such as hoods and downdraft or crossdraft tables. When properly designed, fabricated, and maintained, these devices capture the dye particles close to the point of release and prevent them from entering the worker's breathing zone. However, when local exhaust is used, adequate filters or traps should be provided in the exhaust air line before the air is released inside or outside the plant. It is also important that such filtration apparatus be designed to allow safe maintenance, and that the exhaust system components are kept well maintained.

Engineering controls, such as process enclosure and local exhaust ventilation, can also substantially reduce dye exposure in dye applying operations, as well as in processing industry (post-application) operations where exposure is documented.

NIOSH further recomends that BCDs only be manufactured and used in 
restricted areas of the workplace. Such areas need to be clearly posted with appropriate warning signs, and access to them should be limited to workers informed of both the potential hazards and proper control measures.

For additional information on restricted areas and other approaches to handling actual and potential carcinogens, see the NIOSH pamphlet "A Management Guide to Carcinogens--Regulation and Control," DHEW (NIOSH) Publication No. 77-205.

\section{PERSONAL PROTECTIVE EQUIPMENT}

Q: How can workers be protected during emergencies, maintenance work, equipment failures, and cleaning operations against exposure to hazardous dyes that escape and become airborne despite efforts to contain, capture, or remove them?

A: If hazardous dyes escape into workplace air, then (1) workers must be individually protected against breathing them or coming into skin contact with them, and (2) settled dye particles must be removed and immobilized to prevent them from becoming airborne again.

Inhalation of hazardous dyes that escape capture or containment efforts can be minimized by use of a positive-pressure respirator (air line or battery powered). These provide air to the facepiece under slight pressure. The pressure (1) helps prevent airborne dye from leaking into the mask during inhalation, and (2) reduces the burden of wearing a respirator by diminishing breathing effort.
Persons wearing respirators other than supplied-air types typically breathe with greater effort and sweat more, and may be inadequately protected due to a less than perfect seal. A snug fit is essential where the edges contact the face.

For situations where an air line respirator would not allow sufficient mobility, a half-mask battery powered air purifying respirator with high efficiency filters is recomended. Powered air purifying respirators are inferior, however, to air line respirators for use in areas with substantial dust levels, or in confined spaces. Under emergency conditions, only respirators with a self-contained air supply are suitable.

Whenever respirators are used, it is essential that fitting, maintenance, cleaning, and storage be properly and consistently performed. For general information on selecting, fitting, cleaning, and maintaining respirators, see the NIOSH pamphlets entitled, "Respiratory Protection--An Employer's Manual," DHHS (NIOSH) Publication No. 78-193A, GPO \#017-033-00326-2 $(\$ 4.50)$, and "Respiratory Protection--A Guide for the Employee," DHHS (NIOSH) Publication No. 78-193B, GPO \#017-033-00327-1 (\$3.25). (Ordering information appears on the back cover of this publication.)

Note: Since the particles that can reach the lungs are light enough to stay suspended in workplace air long after heavier particles have settled, airflow patterns may carry them to work positions far from their source, where workers may not be wearing respirators. Because these respirable particles are 
small enough to be invisible, persons at nearby work stations may be unaware of what they may be breathing. Airflow patterns can even move these microscopic particles to more remote areas, such as lunch rooms, management offices, and other areas not typically thought of as hazardous.

This illustrates one more reason why engineering controls are strongly preferred over respirator use for protection against BCD hazards; all employees can be protected, not just the workers known to be exposed.

Settled dye particles must be removed without scattering them back into the air. This means no blowdowns with compressed air, and no dry sweeping. The only safe methods for cleaning settled dye from equipment, ductwork, ledges, floors, etc. are: (1) vacuuming (using high-efficiency filter vacuums, such as those approved for handling asbestos), and (2) wet methods (such as first spraying contaminated surfaces with a fine water mist and then hosing them down with additional water).

Vacuuming is also recommended for the initial removal of dust from heavily contaminated clothing, both imediately after substantial contamination and routinely before changing clothes.

Q: What type of personal protective equipment should be worn by workers who cannot otherwise avoid skin contact with a benzidine congener dye?
A: Skin contact is typically minimized by wearing gloves and protective coveralls.

Gloves are especially important, Bince they prevent skin contact with parent compounds and other contaminants. The gloves must be impermeable to the extent practical. They must be washed before being removed, and checked for pinholes, tears, and similar defects before reuse. Because wearing gloves contaminated on the inside exposes the skin to the contaminant, gloves with dye residue inside must be replaced or thoroughly cleaned. Longsleeved style gloves are recomended to ensure that wrists and forearms aren't contaminated by material entering the cuffs or getting on exposed arms.

Full-body coveralls are also recommended for protecting skin from contact with hazardous dyes. Coveralls should be changed at least daily, and sooner if they become contaminated because of leaks, spills, discharges, etc. Use of disposable outer garments is strongly recommended for two reasons. First, complete removal of BCDs from contaminated garments can be difficult. Reducing agents, such as those commonly used in dye stripping processes, release the toxic parent compound from the dye, which may become entrapped on the garments being laundered.

Second, if contaminated work clothes are worn home, or are taken home for laundering, family members may be inadvertently exposed.

Note that use of bleach, organic solvents, or other strong chemicals 
to clean dye-stained skin impairs the skin's natural protection against the environment, Once impaired, the skin more readily absorbs many hazardous chemicals and becomes more susceptible to infection and dermatitis. The use of any cleaner that contains a strong reducing agent, such as sodium hydrosulfite, is especially dangerous since this chemical transforms benzidine congener dyes back to their toxic parent compounds. Showers should be available where dyestuff exposure can occur, and workers should be required to shower whenever significantly contaminated.

Q: How do workers get the required gloves, coveralls, and (where appropriate) respirator?

A: Under Federal law employers are responsible for protecting workers against workplace hazards, and are required to provide all necessary protective equipment. This equipment must be effective, properly maintained, and readily available to workers.

If reusable protective garments are used, the washing of coveralls, gloves, etc. should be performed or arranged for by the employer, since laundering of BCD-contaminated garments necessitates special handing. Reducing agents should not be used to remove BCD stains, due to conversion of these dyes back to the parent compounds, and the possibility that these would be entrapped on the seemingly clean garment (or on other garments in the batch being washed).

The recommended alternative to laundering is to provide a fresh disposable outer garment daily, and to require it to be changed during the workday if it becomes contaminated. This avoids worker exposure during laundering, and the possibility of residual contaminants being present after washing.

Q: Is all footwear about equally protective against dye exposure?

A: No. Canvas sneakers and other fabric footwear as well as leather shoes or boots will absorb spilled dye, especially when the dye is in liquid form or the footwear is wet. Dye retained on absorbent footwear may later contact the skin; the moist environment in footwear is conducive to skin absorption of various dye components.

For these reasons, washable, nonabsorbent footwear is recommended. Such footwear should be cleaned after each shift and stored in a place free from contamination. An alternative to using nonabsorbent footwear is to use disposable shoe covers on existing footwear.

Q: Wearing full-body coveralls, nonabsorbent footwear, nonabsorbent long-sleeved gloves, and (if appropriate) a respirator could make working in hot work areas extremely -uncomfortable. Are there alternatives?

A: Yes. It is widely recognized that protecting workers individually with personal protective equipment can impose considerable stress on them. In certain environments, such as high heat plus high humidity, this burden may be serious enough to increase the risk of accidental injuries, due to lowered alertness or impaired 
judgment. It may also increase the likelihood of heat illnesses.

In order to minimize reliance on personal protective equipment (and for reasons discussed earlier), NIOSH recommends that hazards be controlled at the Bource. Because exposure is completely eliminated, substitution of a nonhazardous dye can be the simplest and most effective alternative. Where dye substitutes that are known to be gafe are not available, procesa enclosure with local exhaust ventilation to keep the enclosure under negative pressure may provide adequate control.

Where work is performed under hot and/or humid conditions, and use of personal protective equipment is unavoidable, the environment of the work area involved should be made as favorable as possible. For example, ventilation can be increased to remove excess heat or humidity, or air conditioning can be installed. Frequent rest breaks may provide additional protection against severe discomfort.

Obviously many work areas could only be air conditioned with great difficulty; this is yet another reason why engineering controls and other measures that control contaminants at the source have been favored over use of respirators, protective garments, and other personal protective exposure controls.

HEALTH EFFECTS/MEDICAL AND ENVIRONMENTAL EVALUATION

Q: What kind of cancer is known to be a problem for workers who are (or have been) exposed to $\mathrm{BCD} B$ ?
A: Although other types are possible, bladder cancer is found at an unexpectedly high rate among dye, textile, and leather workers exposed to benzidine-based dyes, Cancers are not now specifically essociated with exposure to o-tolidine-besed or o-dianisidine-based dyes; however, animal studies suggest that these are potential human carcinogens.

Q: When bladder cancer was detected in dye workers who manufactured benzidine-based dyes, how long did it take for the tumors to develop?

A: Cases showed a range of 1-40 years between first exposure and the diagnosis of cancer in exposed workers. It is important to note that the minimum amount or length of exposure required to initiate tumor development is not known.

Q: Should workers who are exposed now, or who may have been exposed to these dyes in the past, be medically examined?

A: Yes. The employer should provide a yearly medical examination for each worker potentially exposed to benzidine congener dyes. Retired workers who have worked with or near these dyes, and former dye workers now employed in other industries, are advised to arrange for a medical examination on their own.

Blood in the urine can be an indicator of bladder impairment due to a malignancy. Typically the blood appears without accompanying pain. Blood in the urine can also be caused by a urinary tract infection, by bladder stones, or by a benign 
tumor. In all four cases, the blood may disappear from the urine overnight. However, where a malignancy is the cause, the blood returns, sometimes weeks or months later.

Q: What tests or procedures do physicians perform in evaluating patients who are exposed to benzidine congener dyes?

A: Although there are certain factors (auch as type and amount of exposure) that will influence a physician's judgment, the physician typically:

1. Obtains an occupational and an exposure history.

2: Obtains a medical history with special emphasis on complaints associated with the urinary tract and liver.

3. Performs a phyoical examination emphasizing the kidney and liver.

4. Orders lab testa for liver and kidney function, plus a urinalysis that includes microscopic examination of sediment.

5. Advises the individual of the reoults of the medical examination and lab tests.

In addition, the National Cancer Institute recommends that a cytologic examination of the urine be performed periodically for workers exposed to hezardous dyes (see DHEW (NIH) Publication No. 78-722).

Q: Is free assistance in evaluating working conditions and work practices available?
A: Yes. Employers or employees can ask NIOSH to perform a Health Hazard Evaluation (see back pages of this publication for NIOSH office addresses and phone numberg). These free surveys typically involve on-site sampling, and may include medical evaluations. Results and recommendations are made available to both the employer and employee.

To preserve confidentiality, the identity of specific workers examined does not appear in any medical findings included in the report. Specific findings, however, are provided directly to each individual examined. (Note that medical examinations, if performed, are always voluntary.)

Employers can also ask for technical assistance in hazard recognition and control from state consultation programs funded by the occupational Safety and Health Administration (OSHA). The phone number of the nearest OSHA office can be found in the white pages of the phone directory under "United States Government, Department of Labor."

Another source of assistance is the OSHA compliance inspection. OSHA inspectione may result in orders to correct workplace hazards. These orders can be enforced. 


\author{
APPENDIX A \\ BCD TRADENAMES AND GENERIC NAMES, BY PARENT CHEMICAL \\ Distributed or formerly distributed in the United States \\ as of Auguet 1981
}

\begin{abstract}
Many different tradenames and generic names are used for benzidine congener dyes. As an aid for identification, Appendix A lists tradenames and generic names used for BCDs. Dye names are listed alphabetically and grouped by their parent chemical (benzidine, o-tolidine, or o-dianisidine). All three lists should be checked for the dye name in question. Both imported and domestically produced dyes are listed.
\end{abstract}

Appendix A also lists many tradename dyestuffo that are no longer produced. These are included to (1) help workers find out whether they had been exposed to BCDs in the past, and (2) permit recognition of older inventories of discontinued dyes that could still be used.

Colour Index (C.I.) numbers and generic names are included for those dyes identified by the Toxicology Information Response Center, Oak Ridge National Laboratory as being based on benzidine, o-tolidine, or o-dianisidine. These 1 ists are not, however, exhaustive inventories of every BCD tradename product. To ascertain whether a dye not listed is a benzidine congener dye, consult the Colour Index or contact NIOSH.

Metallized o-dianisidine-based dyes are noted by a "pound sign" (非). These dyes, according to industry sources, may be lesa hazardous to handle than other benzidine congener dyes. Since NIOSH does not now have enough information to determine whether the commercial grade metallized dyes present less of a health hazard, the "pound sign" (\#) should not be construed as NIOSH support for any safety claims. 
BENZIDINE-BASED DYES

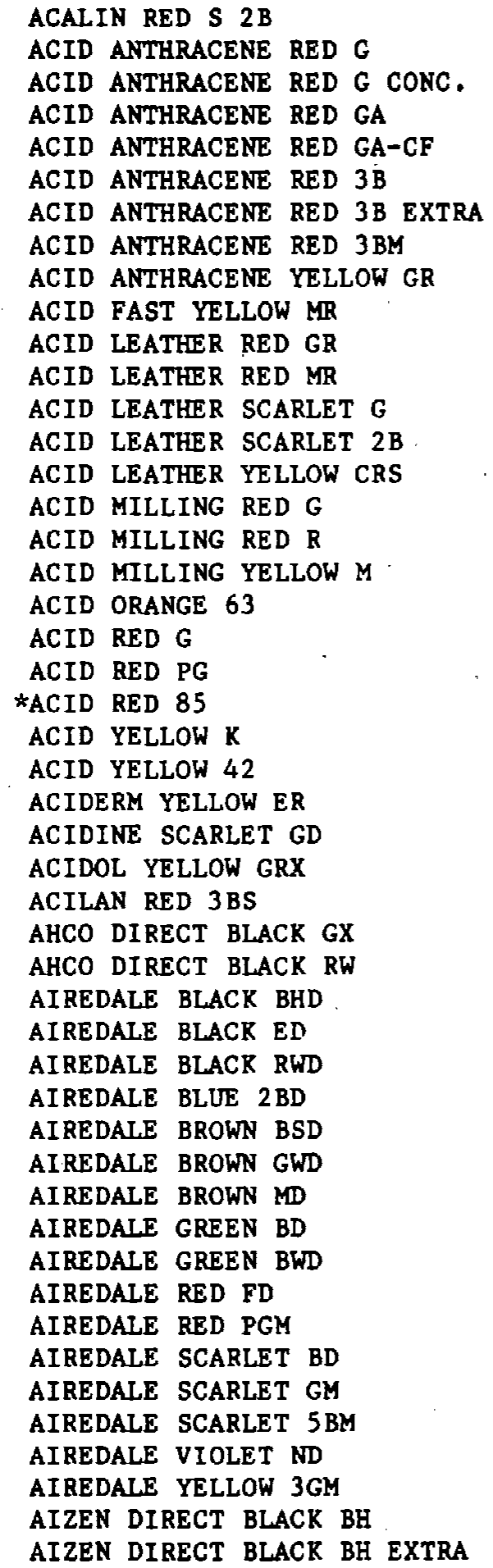

*In current production, 1981.
AIZEN DIRECT BLUE 2BH

AIZEN DIRECT BORDEAUX GH

AIZEN DIRECT BROWN MH

AIZEN DIRECT DARK GREEN BH

AIZEN DIRECT DEEP BLACK EH

AIZEN DIRECT DEEP BLACK GH

AIZEN DIRECT DEEP BLACK RH

AIZEN DIRECT FAST RED FH

AIZEN DIRECT GREEN BH

AIZEN PRIMULA BROWN BRLH

AIZEN PRIMURA BROWN PLH

ALIZARINE CHROME RED G

ALPHANOL FAST ORANGE $R$

ALPHANOL FAST RED G

ALPHANOL FAST YELLOW F

ALPHANOL FAST YELLOW H5G

ALTAZINE BLACK BH

ALTOCHROME MILLING SCARLET G

ALTOCHROME SCARLET $G$

AIZEN DIRECT VIOLET LNH

AMACID FAST YELLOW RS

AMACID FAST YELLOW RS EX. AMACID MILLING ORANGE PR

AMACID MILLING RED PGS

AMACID MILLING SCARLET G

AMACID MILLING SCARLET 3R

AMACID MILLING SCARLET 3R CONC.

AMACID MILLING YELLOW 5G

AMANIL BLACK GL

AMANIL BLACK WD

AMANIL BLUE 2BX

AMANIL BORDEAUX B

AMANIL BROWN D3G

AMANIL BROWN MR

AMANIL CATECHINE $3 G$

AMANIL DEVELOPED BLACK BHSW

AMANIL FAST BROWN BRL

AMANIL FAST BROWN HP

AMANIL FAST BROWN RLH

AMANIL FAST ORANGE GLZ

AMANIL FAST ORANGE PRZ

AMANIL FAST RED FS

AMANIL FAST SCARLET B

AMANIL FAST VIOLET N

AMANIL GARNET H

AMANIL GARNET RB

AMANIL GREEN B

AMANIL GREEN GX 
BENZIDINE-BASED DYES

(continued)

AMANIL GREEN LT

AMANIL NAVY BLUE BHSW

AMANIL ORANGE $Y$

AMANIL RAYON BROWN B

AMANIL RUBINE R

AMANIL RUBINE $R, Y$

AMANIL RUBINE $Y$

AMANIL SUPRA BROWN LBL

AMIDINE BLACK RBN

AMIDINE BLUE 2B CONC.

AMIDINE BLUE 2BNB CONC.

AMIDINE BROWN DMB

AMIDINE BROWN M CONC

AMIDINE BROWN 3GC 250\%

AMIDINE DARK GREEN N

AMIDINE FAST RED F NEW

AMIDINE FAST SCARLET BN CONC.

AMIDINE GREEN GX

AMIDINE GREEN M SPECIAL

AMIDINE GREEN 2BN

AMIDINE VIOLET $N$

AMINDINE VIOLET $N$

ANTHRA MILLING RED $G$

ANTHRA MILLING RED 3B

ANTHRA RED G

ANTHRA RED 3B

ANTRACROMO YELLOW

APOCID MILLING RED $G$

APOMINE BLACK GX

APOMINE GREEN B

APOMINE GREEN GX

ATLANTIC BLACK BD

ATLANTIC BLACK C

ATLANTIC BLACK E

ATLANTIC BLACK EA

ATLANTIC BLACK GAC

ATLANTIC BLACK GG

ATLANTIC BLACK GXCW

ATLANTIC BLACK GXOO

ATLANTIC BLACK RW

ATLANTIC BLACK SD

ATLANTIC BLUE 2B

ATLANTIC BORDEAUX B

ATLANTIC BROWN BCW

ATLANTIC BROWN BP

ATLANTIC BROWN M

ATLANTIC BROWN $3 \mathrm{GN}$

ATLANTIC CONGO BROWN $G$
ATLANTIC CONGO RED

ATLANTIC DARK GREEN

ATLANTIC DARK GREEN B

ATLANTIC DARR GREEN BG

ATLANTIC FAST BROWN BRL

ATLANTIC FAST ORANGE $R$

ATLANTIC FAST ORANGE 3G

ATLANTIC FAST RED F

ATLANTIC FAST YELLOW PRA

ATLANTIC GARNET B

ATLANTIC GREEN WT

ATLANTIC GREEN 2B

ATLANTIC RESIN FAST BROWN BRL

ATLANTIC SCARLET B

ATLANTIC VIOLET N

ATUL ACID MILLING RED G

ATUL CONGO RED

ATUL DEVELOPED BLACK BT

ATUL DIRECT BLACK E

ATUL DIRECT BLUE 2B

ATU DIRECT BORDEAUX BR

ATUL DIRECT BROWN BN

ATUL DIRECT BROWN MR

ATUL DIRECT BROWN MY

ATUL DIRECT DARK GREEN P

ATUL DIRECT FAST ORANGE G

ATUL DIRECT FAST ORANGE $R$

ATUL DIRECT GARNET B

ATUL DIRECT GARNET B, BY

ATUL DIRECT GARNET BY

ATUL DIRECT GREEN B

ATUL DIRECT GREEN G

ATUL DIRECT GREEN P

ATUL DIRECT VIOLET N

AZANOL MILLING SCARLET G

AZINE BROWN $M$

AZINE BROWN 2RG

AZINE BROWN 3G

AZINE CORINTH $G$

AZINE DARK GREEN BH/C

AZINE DEEP BLACK EW

AZINE DEEP BLACK 3RL

AZINE DIAZO BLACK BHK

AZINE FAST RED FC

AZINE GREEN BX

AZINE LIGHT BROWN GR

AZINE SCARLET BX

AZO MILLING RED G 
BENZIDINE-BASED DYES

(continued)

AZO MILLING RED 3B

AZO MILLING YELLOW $3 G$

AZOCARD BLACK EW

AZOCARD BLACR RW

AZOCARD BLUE BH

AZOCARD BLUE 2B

AZOCARD BROWN M

AZOCARD BROWN $3 \mathrm{G}$

AZOCARD BROWN 3GR

AZOCARD BROWN 5G

AZOCARD DARK GREEN B

AZOCARD FAST RED $\boldsymbol{F}$

AZOCARD GREEN B

AZOCARD GREEN G

AZOCARD RED CONGO

AZOCARD VIOLET N

AZOGEN BLACK BH

AZOMINE BLACK BH

AZOMINE BLACR EWO

AZOMINE BLUE 2B

AZOMINE BROWN M

AZOMINE GREEN B

BAYGENAL BROWN CTR

BAYGENAL RED CG

BELACHROME FAST YELLOW .R

BELACID MILLING RED G

BELACID MILLING SCARLET 3R

BELACID MILLING YELLOW R

BELACID MILLING YELLOW 5G

BELAMINE BLACK GX

BELAMINE BLUE 2B

BELAMINE BORDEAUX B

BELAMINE DIAZO BLACR, BH

BELAMINE FAST BROWN BP

BELAMINE FAST BROWN BRLL

BELAMINE FAST BROWN M

BELAMINE FAST ORANGE GL

BELAMINE FAST RED FC

BELAMINE FAST SCARLET B

BELAMINE GREEN BX

BENCIDAL BLACK E

BENCIDAL BLACK RW

BENCIDAL BLUE 2B

BENCIDAL BROWN 3G

BENCIDAL DARK GREEN B

BENCIDAL FAST BROWN $M$

BENCIDAL FAST RED $F$

BENCIDAL FAST VIOLET N

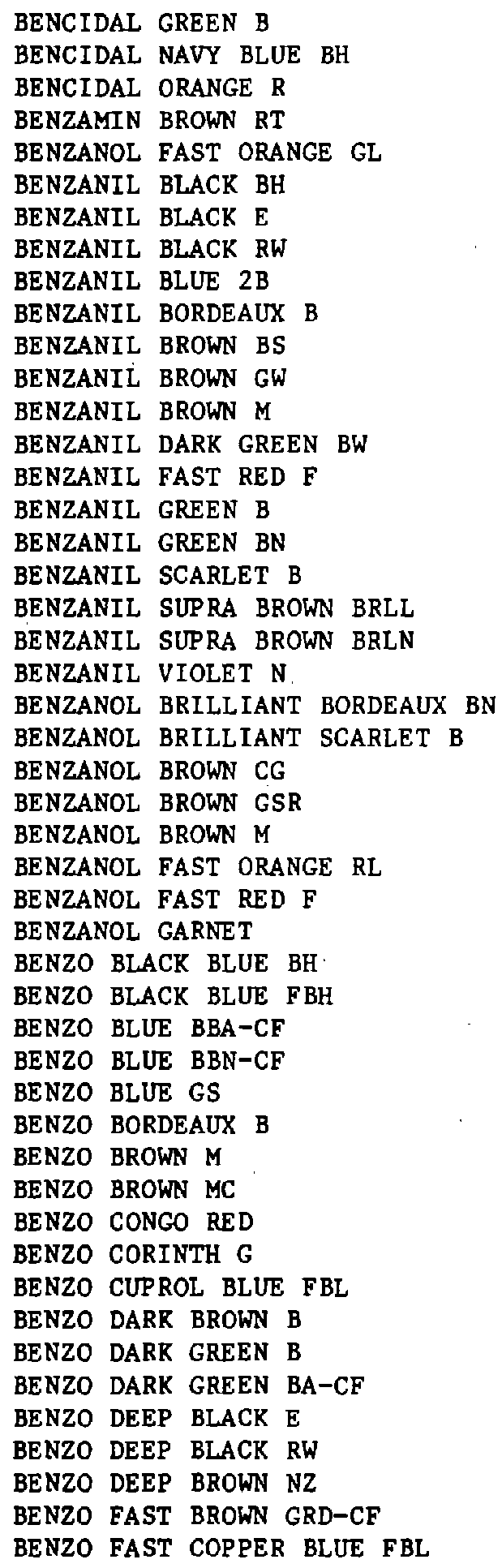


BENZIDINE-BASED DYES

(continued)

BENZO FAST COPPER BLUE FBLA-CF

BENZO FAST RED $F$

BENZO GREEN B

BEN2O GREEN BG-CF

BEN2O GREEN CA-CF

BENZO GREEN GA-CF

BENZO LEATHER BLACK E

BENZO LEATHER BLACK RW

BENZO ORANGE BROWN D3G

BENZO SCARLET B

BENZO VIOLET N

BENZOFORM BLACK BCN-CE

BENZORCO MILLING RED 3 BM

BENZYL FAST RED GRG

BENZYL FAST YELLOW RS

BENZYL RED GR

BENZYL RED GS

BENZYL RED MG

BENZYL RED MR

BENZYL RED RS

BENZYL SCARLET BS

BENZYL YELLOW 8G

BERKSHIRE DIAZO BLACK BH

BERKSHIRE DIAZO BLACK BHSW

BERKSHIRE DIRECT BLACK RX

BERKSHIRE DIRECT BLUE 2B

BERKSHIRE DIRECT BROWN 3GN

BERKSHIRE DIRECT DARK GREEN WS

BERKSHIRE DIRECT FAST BROWN $M$

BERKSHIRE DIRECT FAST ORANGE $3 \mathrm{G}$

BERKSHIRE DIRECT GREEN BX

BERKSHIRE DIRECT GREEN BXN

BERKSHIRE DIRECT GREEN LTCW

BERNACHROME YELLOW RG

BLACK 2EMBL

BLACK 3EMBI

BLACK 4EMBL

BLUE BH

BLUE 2B

BLUE 2B SALT

BORDEAUX DIRECT

BRASILAMINA BLACK GN

BRASILAMINA BLUE 2B

BRASILAMINA BROWN GN

BRASILAMINA BROWN GR

BRASILAMINA CONGO 4B

BRASILAMINA FAST BROWN 3RA

BRASILAMINA FAST RED F
BRASILAMINA GARNET B

BRASILAMINA GREEN B

BRASILAMINA GREEN G

BRASILAMINA VIOLET 3R

BRASILAZOL BLACK BH

BRILLIANT CHROME LEATHER BLACK H BRILLIANT MILLING RED R EXTRA

BRILLIANT MILLING RED RA

BRILLIANT MILLING RED RA-CF

BRILLIANT MILLING YELLOW. 6G

BRILLIANT YELLOW 6G

BROWN M

BROWN 4EMBL

BUCACID ORANGE $R$

BUCACID SILR RED 3B

BUFFALO GARNET R

C.I. ACID ORANGE 45

C.I. ACID ORANGE 63

C.I. ACID RED 85

C.I. ACID RED 85, DISODIUM SALT

C.I. ACID RED 89

C.I. ACID RED 97, DISODIUM SALT

C.I. ACID YELLOW 42

C.I. ACID YELLOW 42, DISODIUM SALT

C.I. ACID YELLOW 44

C.I. ACID YELLOW 44, DISODIUM SALT

C.I. DIRECT BLACK 4

C.I. DIRECT BLACK 4, DISODIUM SALT

C.I. DIRECT BLUE 158

C.I. DIRECT BLUE 158, TETRASODIUM SALT

C.I. DIRECT BLUE 2

C.I. DIRECT BLUE 2, TRISODIUM SALT

C.I. DIRECT BLUE 6

C.I. DIRECT BLUE 6, TETRASODIUM SALT

C.I. DIRECT BROWN

C.I. DIRECT BROWN 1

C.I. DIRECT BROWN 1, DISODIUM SALT

C.I. DIRECT BROWN 111

C.I. DIRECT BROWN 154

C.I. DIRECT BROWN 154, DISODIUM SALT

C.I. DIRECT BROWN 2

C.I. DIRECT BROWN 2, DISODIUM SALT

C.I. DIRECT BROWN 31

C.I. DIRECT BROWN 31, TETRASODIUM SALT

C.I. DIRECT BROWN 59

C.I. DIRECT BROWN 6 
BENZIDINE-BASED DYES

(continued)

C.I. DIRECT BROWN 6, DISODIUM SALT

C.I. DIRECT BROWN 74

C.I. DIRECT BROWN 95

C.I. DIRECT GREEN

C.I. DIRECT GREEN 1

C.I. DIRECT GREEN 1, DISODIUN SALT

C.I. DIRECT GREEN 6, DISODIUM SALT

C.I. DIRECT GREEN 8

C.I. DIRECT ORANGE I

C.I. DIRECT ORANGE 8

C.I. DIRECT ORANGE 8, DISODIUT SALT

C.I. DIRECT RED 1

C.I. DIRECT RED 1, DISODIUM SALT

C.I. DIRECT RED 10

C.I. DIRECT RED 10, DISODIUM SALT

C.I. DIRECT RED 13

C.I. DIRECT RED 13, DISODIUM SALT

C.I. DIRECT RED 28.

C.I. DIRECT RED 28, DISODIUM SALT

C.I. DIRECT RED 37, DISODIUM SALT

C.I. DIRECT RED 89

C.I. DIRECT VIOLET 1

C.I. DIRECT VIOLET 1, DISODIUM SALT

C.I. DIRECT VIOLET 22

C.I. DIRECT YELLOW 20

C.I. MORDANT YELLOW 26

C.I. MORDANT YELLOW 26, TETRASODIUM SALT

$\star C . I .22120$

*C.I. 22130

C.I. 22145

C.I. 22155

C.I. 22195

*C.I. 22240

*C.I. 22245

*C.I. 22310

*C.I. 22311

C.I. 22345

C.I. 22370

C.I. 22410

C.I. 22480

C.I. 22570

*C.I. 22590

*C.I. 22610

C.I. 22870

C.I. 22880

C.I. 22890

C.I. 22910
C.I. 23900

C.I. 23910

C.I. 24555

C.I. 30045

*C.I. 30120

*C.I. 30140

*C.I. 30145

*C.I. 30235

*C.I. 30245

$\star C . I .30280$

*C.I. 30295

C.I. 30315

*C.I. 35660

*C.I. 36300

CALCOCID MILLING RED G

CALCOCID MILLING RED GP

CALCOCID MILLING RED 3B

CALCOCID MILLING YELLOW R

CALCODUR BROWN BRL

CALCOLOID DIAZO BLACR BHL

CALCOMINE BLACK

CALCOMINE BLACK EXI

CALCOMINE BLUE 2B

CALCOMINE BRIGHT GREEN

CALCOMINE BRIGHT GREEN BP

CALCOMINE . BROWN B

CALCOMINE BROWN BN

CALCOMINE BROWN MCW

CALCOMINE BROWN MRS

CALCOMINE BROWN RP

CALCOMINE CATECHU 2B

CALCOMINE DARK GREEN BG

CALCOMINE DIAZO BLACK BHD

CALCOMINE DIAZO BLACR BTCW

CALCOMINE GARNET BY

CALCOMINE GREEN BY

CALCOMINE GREEN GN

CALCOMINE NAVY BL

CALCOMINE RED FC

CALCOMINE SCARLET B'

CALCOMINE SCARLET BL

CALCOMINE VIOLET $N$

CALCOMINE YELLOW BROWN $K$

CALICO FLAVINE R

CAMELON SCARLET G

CARBIDE BLACR E

CARBIDE BLACK ER

CARBIDE BLACR FC

*In current production, 1981. 
BENZIDINE-BASED DYES

(continued)

CETIL ANTHRACENE RED 3B

CHLORAMINE BLACR BH

CHLORAMINE BLACR C

CHLORAMINE BLACK EC

CHLORAMINE BLACK ERT

CHLORAMINE BLACR EX

CHLORAMINE BLACR EXR

CHLORAMINE BLACR E2B

CHLORAMINE BLACK W

CHLORAMINE BLACR XO

CHLORAMINE BLUE 2B

CHLORAMINE BROWN $M$

CHLORAMINE BROWN MR

CHLORAMINE BROWN 2ME

CHLORAMINE BROWN 2R

CHLORAMINE CARBON BLACK S

CHLORAMINE CARBON BLACR SJ

CHLORAMINE CARBON BLACR SN

CHLORAMINE FAST BROWN BRL

CHLORAMINE FAST CUTCH BROWN PL

CHLORAMINE FAST RED

CHLORAMINE FAST RED F

CHLORAMINE FAST RED FB

CHLORAMINE FAST RED FS

CHLORAMINE GARNET NR

CHLORAMINE GARNET R

CHLORAMINE GARNET RS

CHLORAMINE GREEN B

CHLORAMTNE GREEN BC

CHLORAMINE GREEN 2B

CHLORAMINE GREEN 3G

CHLORAMINE RED B

CHLORANTINE FAST BROWN BRLL

CHLORAZOL BLACK BH

CHLORAZOL BLACK E

CHLORAZOL BLACK EA

CHLORAZOL BLACR EN

CHLORAZOL BLACK LF

CHLORAZOL BLACR LFA

CHLORAZOL BLUE B

CHLORAZOL BLUE BP

CHLORAZOL BORDEAUX B

CHLORAZOL BORDEAUX BP

CHLORAZOL BROWN LF

CHLORAZOL BROWN M

CHLORAZOL BROWN MP

CHLORAZOL BURL BLACR E

CHLORAZOL CORINTH GW
CHLORAZOL DARK GREEN PL CHLORAZOL FAST RED FP

CHLORAZOL FAST RED FS

CILORAZOL GREEN BN

CHLORAZOL GREEN BNP

CHLORAZOL LEATHER BLACK BH

CHLORAZOL LEATHER BLACR ENP

CHLORAZOL PAPER BROWN

CHLORAZOL PAPER BROWN B

CHLORAZOL PAPER GREEN BN

CHLORAZOL SILR BLACR G

CHLORAZOL VIOLET N

CHOCOLATE EMBL

CHROMAZOL YELLOW CR

CHROME CITRONINE RD

CHROME FAST RED F

CHROME FAST RED FB

CHROME FAST RED FW

CHROME LEATHER BLACR BH

CHROME LEATHER BLACR CR

CHROME LEATHER BLACR DS

CHROME LEATHER BLACR E

CHROME LEATHER BLACK EC

CHROME LEATHER BLACK EM

CHROME LEATHER BLACR ER

CHROME LEATHER BLACK FC

CHROME LEATHER BLACK G

CHROME LEATHER BLACR RM

CHROME LEATHER BLUE 2B

CHROME LEATHER BORDEAUX BC

CHROME LEATHER BRILLIANT BLACK ER

CHROME LEATHER BROWN BRLL

CHROME LEATHER BROWN BRSL

CHROME LEATHER BROWN BS

CHROME LEATHER BROWN M

CHROME LEATHER BROWN 56

CHROME LEATHER DARR BLUE BHM

CHROME LEATHER DARR GREEN N

CHROME LEATHER DARK GREEN S

CHROME LEATHER DARR GREEN S CONC.

CHROME LEATHER FAST RED N

CHROME LEATHER GREEN B

CHROME LEATHER RED F

CHROME LEATHER RED F EXTRA

CHROME LEATHER SCARLET BS

CHROME PRINTING YELLOW RG

CHROMINE YELLOW R

CHROMO CITRONINE RD 
BENZIDINE-BASED DYES

(continued)

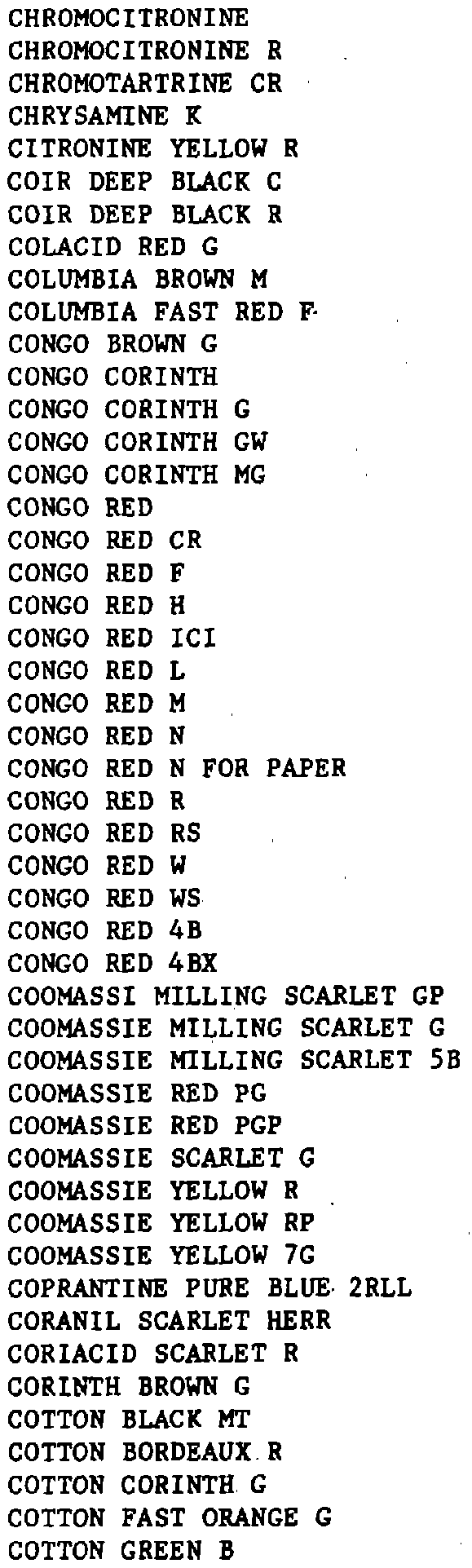

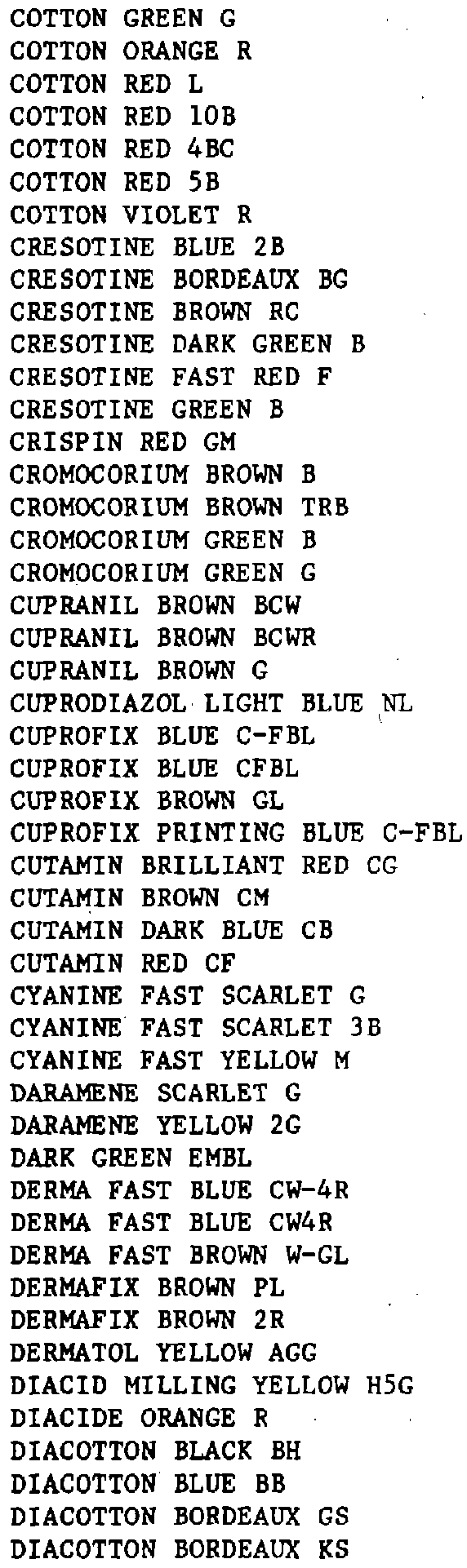


BENZIDINE-BASED DYES

(continued)

DIACOTTON BROWN CB

DIACOTTON BROWN M

DIACOTTON BROWN $3 G$

DIACOTTON CONGO RED

DIACOTTON DARR GREEN

DIACOTTON FAST RED F

DIACOTTON GREEN B

DIALUMINOUS BROWN BRS

DIMACIDE YELLOW F-RA CONC.

DIMACIDE YELLOW F-RA CONC. C

DIAMINE BLACK BH

DIAMINE BLACK BHM

DIAMINE BLUE

DIAMINE BLUE BB

DIAMINE BLUE 2B

DIAMINE BORDEAUX B

DIAMINE BORDEAUX BA-CF

DIAMINE BORDEAUX BC

DIAMINE BORDEAUX CGN

DIAMINE BROWN B

DIAMINE BROWN BC

DIAMINE BROWN $M$

DIAMINE BROWN MBA-CF

DIAMINE BROWN MR

DIAMINE BROWN MRC

DIAMINE BROWN 3GN

DIAMINE BROWN 3GN-CF

DIAMINE BROWN 3GPA

DIAMINE DARK GREEN B

DIAMINE DARK GREEN N

DIAMINE DEEP BLACK RW

DIAMINE DIRECT BLACK RW

DIAMINE FAST RED $F$

DIAMINE FAST RED FA-CF

DIAMINE FAST RED N

DIAMINE FAST RED OJCD

DIAMINE GREEN

DIAMINE GREEN B

DIAMINE GREEN G

DIAMINE GREEN GM

DIAMINE SCARLET BA-CF

DIAMINE VIOLET $N$

DIAMINOGENE VELOUR BLACK B

DIANIL DARK BLUE $\mathrm{H}$

DIAPHTAMINE BLACK BH

DIAPHTAMINE BLACK MT

DIAPHTAMINE BLUE BB

DIÁPHTAMINE BROWN M
DIAPHTAMINE BROWN 3G

DIAPHTAMINE BROWN 3GC

DIAPHTAMINE BROWN 3GR

DIAPHTAMINE FAST BLACK FE

DIAPHTAMINE FAST BROWN TB

DIAPHTAMINE FAST ORANGE PG

DIAPHTAMINE FAST ORANGE PGS

DIAPHTAMINE FAST RED B

DIAPHTAMINE FAST RED FC

DIAPHTAMINE GREEN B

DIAPHTAMINE GREEN GX

DIAPHTAMINE LIGHT BROWN BRLL

DIAPHTAMINE ORANGE $R$

DIAPHTAMINE VIOLET N

DIAPHTHAMINE BROWN B

DIAZAMINE BROWN 2R

DIAZAMINE ORANGE BO

DIAZINE BLACK BHC

DIAZINE BLACK H

DIAZINE BLACK HDW

DIAZINE BLACK HNJ

DIAZINE BLUE 2B

DIAZINE BROWN $M$

DIAZINE BROWN MWR

DIAZINE BROWN OR

DIAZINE DARK GREEN BO

DIAZINE DARK GREEN P

DIAZINE DIRECT BLACK BR

DIAZINE DIRECT BLACK R

DIAZINE FAST BROWN RSL

DIAZINE FAST RED F

DIAZINE GREEN B

DIAZINE GREEN DB

DIAZINE VIOLET N

*DIAZO BLACK BH

DIAZO BLACK BHN-CF

DIAZO BLACK BHSW

DIAZO BLACK BHSWK

DIAZO BLACK CR

DIAZO BLACK RW

DIAZO BROWN DDL

DIAZO BROWN MC

DIAZO DIRECT BLACK N

DIAZO FAST BLACK BH

DIAZO FAST BLACK MBH

DIAZO NAVY BLUE BH

DIAZOL BLACK BH

DIAZOL BLACK ER

*In current production, 1981. 
BENZIDINE-BASED DYES

(continued)

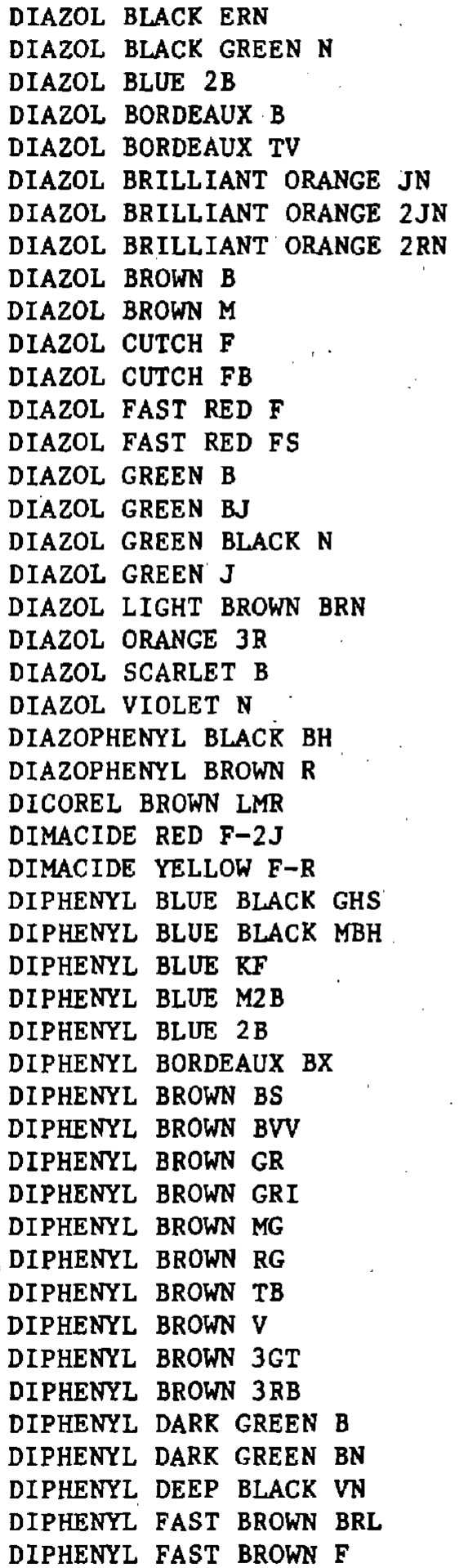

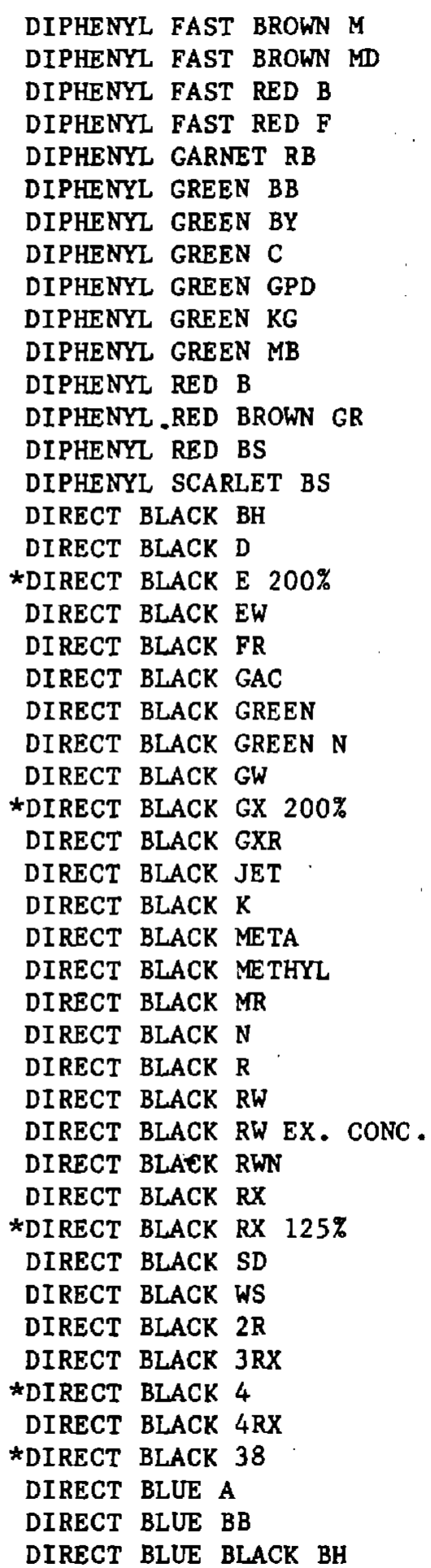


BENZIDINE-BASED DYES

(continued)

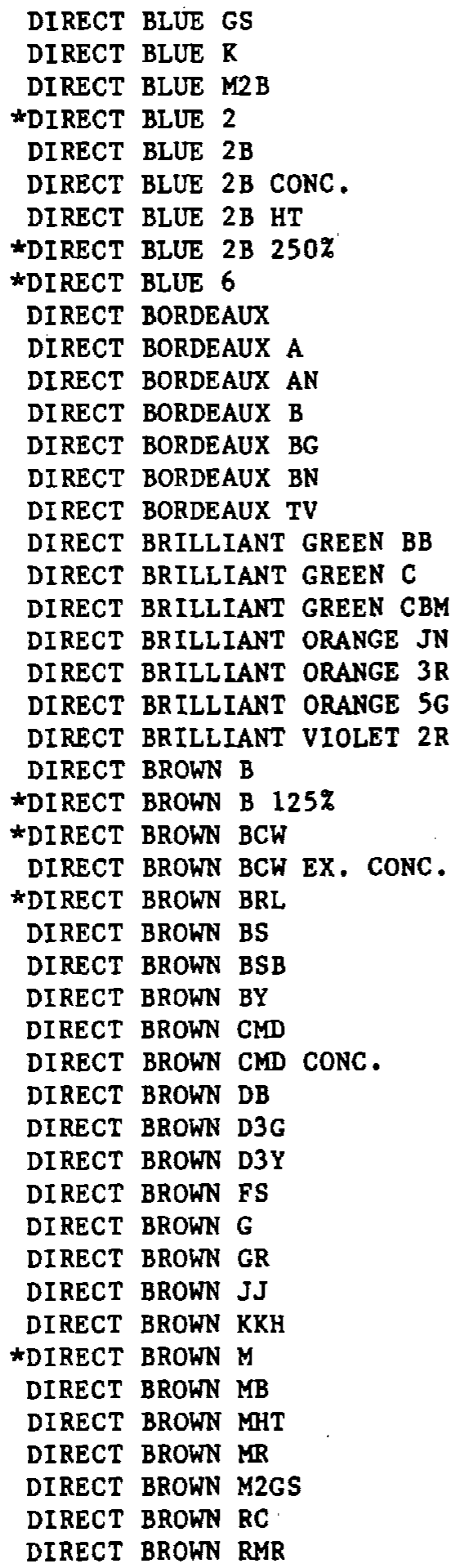

*In current production, 1981.

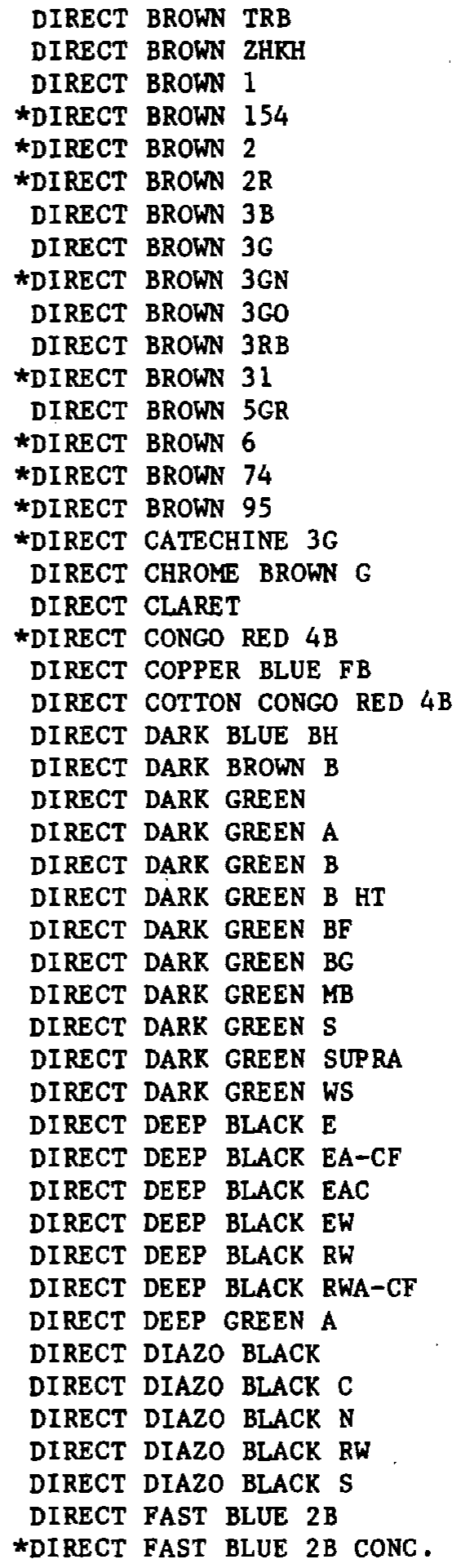




\section{BENZIDINE-BASED DYES}

(continued)

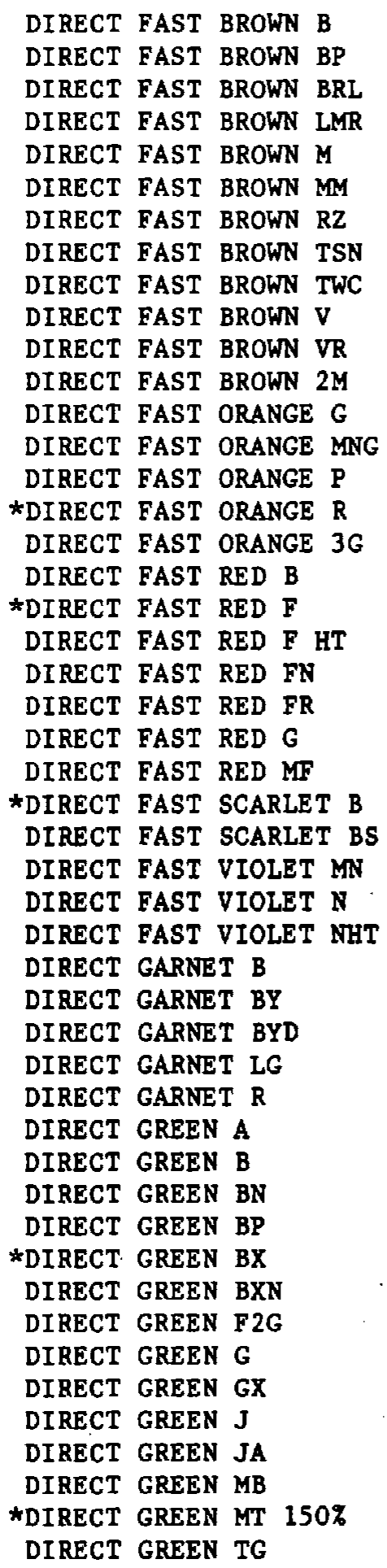

*In current production, 1981.

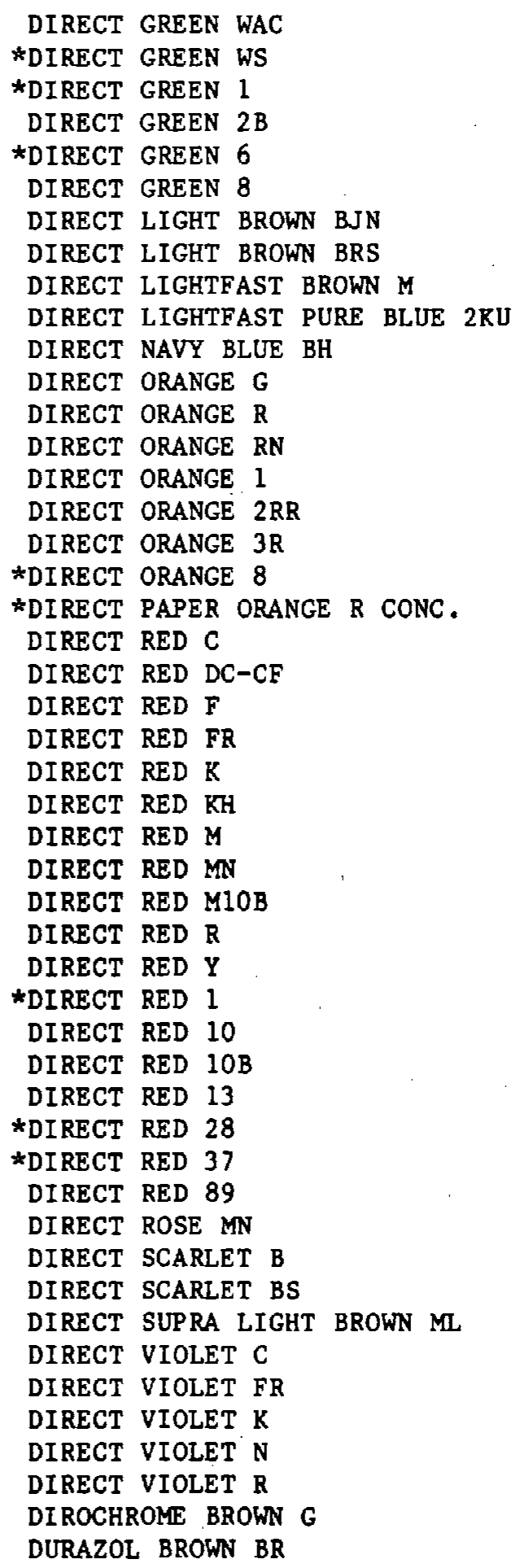


BENZIDINE-BASED DYES

(continued)

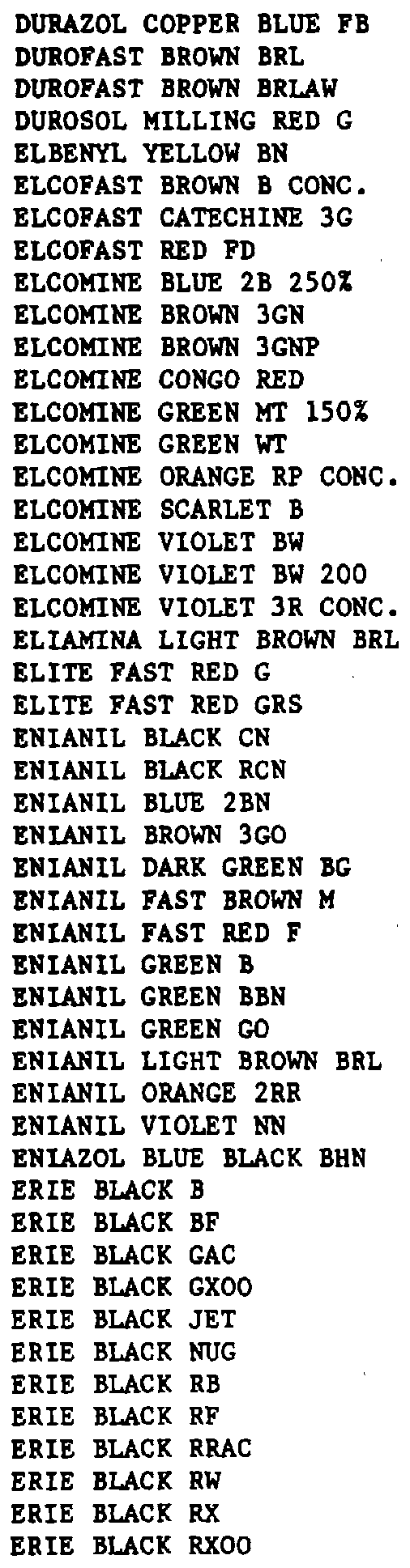

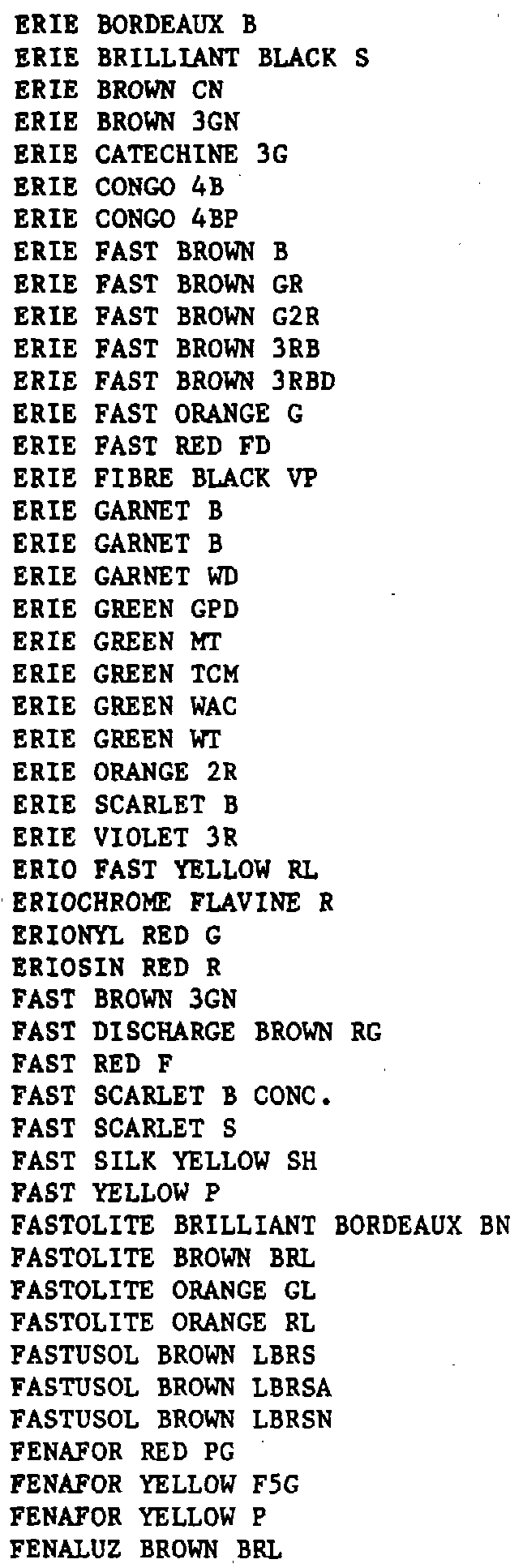


BENZIDINE-BASED DYES

(continued)

FENAMIN BLACR E

FENAMIN BLACR RW

FENAMIN BLUE 2B

FENAMIN BORDEAUX B

FENAMIN BROWN BP

FENAMIN BROWN M

FENAMIN BROWN PBL

FENAMIN BROWN $3 G$

FENAMIN DIAZO BROWN RL

FENAMIN DIAZO BROWN 4RL

FENAMIN FAST BROWN G

FENAMIN FAST RED $F$

FENAMIN GREEN A

FENAMIN GREEN B

FENAMIN GREEN G

FENAMIN GREEN M

FENAMIN NAVY BLUE H

FENAMIN ORANGE $R$

FENAMIN SCARLET B

FENAMIN SCARLET BP

FENAZO RED FG

FENAZO RED FR

FENAZO YELLOW $S$

FIBRE BLACK VF

FINISH BROWN BR

FIXANOL BLACK E

FIXANOL BLUE BH

FIXANOL BLUE 2B

FIXANOL BROWN LF

FIXANOL BROWN $M$

FIXANOL GREEN BN

FIXANOL RED FS

FIXANOL VIOLET N

FOLAN FAST SCARLET 4R

FOLAN RED $\mathbf{G}$

FOLAN YELLOW $\mathbf{G}$

FOLAN YELLOW $7 G$

FORMALINE BLACR C

FORMIC BLACK C

FORMIC BLACR CW

FORMIC BLACR EA

FORMIC BLACK MTG

FORMIC BLACK MTR

FORMIC BLACK TG

FORMO DIRECT BLUE 2B

FORMO DIRECT BORDEAUX GS

FORMO DIRECT BROWN CB

FORMO DIRECT BROWN $M$
FORMO DIRECT CONGO RED

FORMO DIRECT DARR GREEN B

HAEMOMEDICAL

HAEMONORM

HAVANA EMB

HELION BROWN BRSL

HELION ORANGE 2G

HEMORRHAGYL

HEXADERM RED MRG

HISPACID MILLING SCARLET SGN

HISPACID MILLING SCARLET $3 G$

HISPACID MILLING YELLOW 5G

HISPALUZ BROWN BRL

HISPAMIN BLACK EF

HISPAMIN BLACK 3RX

HISPAMIN BLUE 2B

HISPAMIN BROWN CTN

HISPAMIN BROWN DB

HISPAMIN CONGO 4B

HISPAMIN FAST BROWN NZ

HISPAMIN FAST BROWN 3R2B

HISPAMIN FAST RED FN

HISPAMIN GARNET BF

HISPAMIN GREEN B

HISPAMIN GREEN GO

HISPAMIN GREEN WT

HISPAMIN ORANGE PGN

HISPAMIN ORANGE PR

HISPAMIN ORANGE $R$

HISPAMIN VIOLET $3 R$

HONEY YELLOW 3GN

INDIGO BLUE 2B

INDOXINE KL

INTERMET BRILLIANT BLUE 2BL

INTRALITE FAST BROWN BRLL

INTRALITE FAST SCARLET BNLL

INTRALITE SCARLET BNLL

INTRAMET BRILLIANT BLUE 2BL INTRAMET BRILLIANT BLUE 2BL INTRANYL SCARLET $R$

INTRAZONE FAST ORANGE 2RN INTRAZONE FAST RED GRG

JAPANOL BLACR BHR

JAPANOL BROWN $M$

JAPANOL BROWN RA

JAPANOL FAST RED $F$

JAPANOL FAST RED 1 
BENZIDINE-BASED DYES

(continued)

JAPANOL VIOLET J

RAYAKU CONGO RED

KAYAKU DIRECT BLACK BH

RAYAKU DIRECT BLUE BB

KAYAKU DIRECT BROWN M

KAYAKU DIRECT BROWN $3 G$

RAYAKU DIRECT DARK GREEN B

RAYAKU DIRECT FAST RED F

RAYAKU DIRECT GREEN B

KAYAKU DIRECT SCARLET B.

RAYAKU DIRECT SCARLET B NEW

RAYANOL MILLING RED PG

KAYANOL RED PG

RAYARUS SUPRA BROWN BRS

KAYARUS SUPRA SCARLET BNL

RCA ACID MILLING YELLOW $M$

KCA LIGHT FAST BROWN BR

KCA SILK RED G

KOROSTAN RED G

LANAPERL FAST RED $3 G$

I.ANAPERL FAST YELLOW GR

LANAPERL RED $G$

LIBIA BROWN B

LIGHT FAST BROWN BR

MAHOGANY EMBL

MELANTHERINE BH

MELANTHERINE BHX

METACHROME RED $F$

METADIAZOL BROWN 2JO

METADIAZOL BROWN 3JO

METADIAZOL BROWN 4JO

MIDLON ORANGE PR

MIDLON RED PG

MIDLON YELLOW PR

MIDLON YELLOW PROPYL

MILLING BRILLIANT SCARLET GN

MILLING FAST ORANGE $R$

MILLING FAST ORANGE 2R

MILLING FAST RED G

MILLING FAST RED GL

MILLING FAST RED PG

MILLING FAST SCARLET 4R

MILLING FAST YELLOW R

MILLING FAST YELLOW 5G

MILLING ORANGE $R$

MILLING RED A

MILLING RED G

MILLING RED J

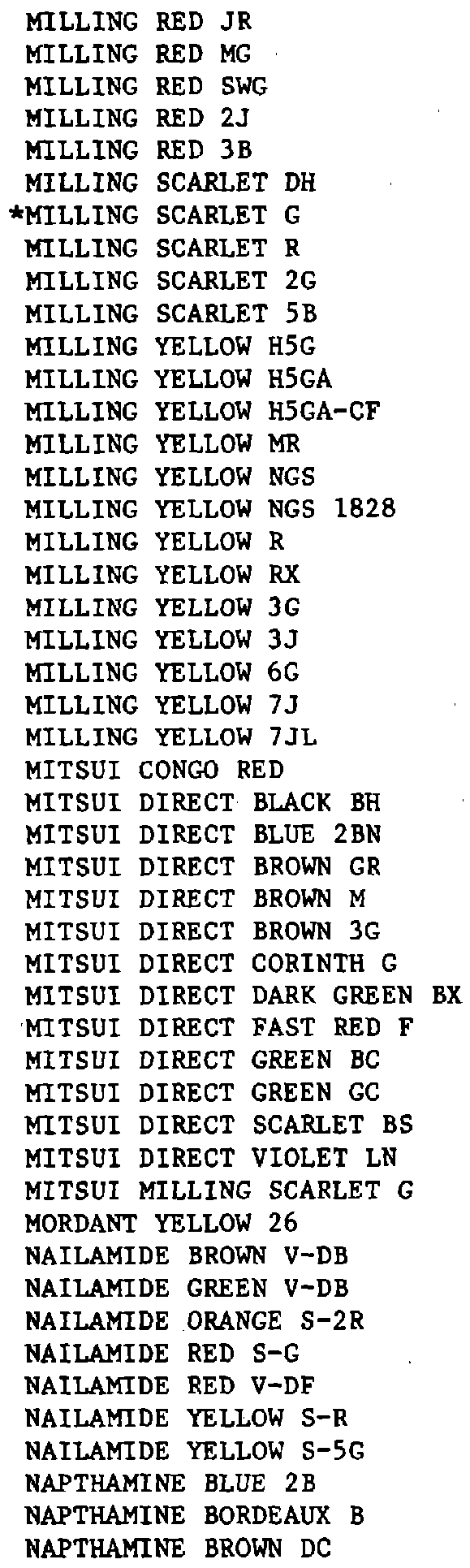

MILLING RED JR

MILLING RED MG

MILLING RED SWG

MILLING RED 2J

MILLING RED 3B

MILLING SCARLET DH

*MILLING SCARLET G

MILLING SCARLET $R$

MILLING SCARLET 2G

MILLING SCARLET 5B

MILLING YELLOW H5G

MILLING YELLOW H5GA

MILLING YELLOW H5GA-CF

MILLING YELLOW MR

MILLING YELLOW NGS

MILLING YELLOW NGS 1828

MILLING YELLOW $R$

MILLING YELLOW RX

MILLING YELLOW $3 \mathrm{G}$

MILLING YELLOW 3J

MILLING YELLOW 6G

MILLING YELLOW $7 \mathrm{~J}$

MILLING YELLOW 7JL

MITSUI CONGO RED

MITSUI DIRECT BLACK BH

MITSUI DIRECT BLUE 2BN

MITSUI DIRECT BROWN GR

MITSUI DIRECT BROWN $M$

MITSUI DIRECT BROWN 3G

MITSUI DIRECT CORINTH $G$

MITSUI DIRECT DARK GREEN BX

MITSUI DIRECT FAST RED F

MITSUI DIRECT GREEN BC

MITSUI DIRECT GREEN GC

MITSUI DIRECT SCARLET BS

MITSUI DIRECT VIOLET LN

MITSUI MILLING SCARLET $G$

MORDANT YELLOW 26

NAILAMIDE BROWN V-DB

NAILAMIDE GREEN V-DB

NAILAMIDE ORANGE S-2R

NAILAMIDE RED S-G

NAILAMIDE RED $V$-DF

NAILAMIDE YELLOW S-R

NAILAMIDE YELLOW S-5G

NAPTHAMINE BLUE 2B

NAPTHAMINE BORDEAUX B

NAPTHAMINE BROWN DC 
BENZIDINE-BASED DYES

(continued)

PHENAMINE BLUE BB

PHENAMINE BLUE BBN

PHENAMINE BORDEAUX B

PHENAMINE BROWN MB

PHENAMINE BROWN $3 G$

PHENAMINE DARK GREEN B

PHENAMINE FAST BROWN GR

PHENAMINE FAST BROWN T

PHENAMINE FAST BROWN TSL

PHENAMINE FAST BROWN TWC

PHENAMINE FAST RED $F$

PHENAMINE GREEN BG

PHENAMINE GREEN C

PHENAMINE GREEN G

PHENAMINE GREEN YY

PHENAMINE SCARLET B

PHENAZO BLACR BH

PHENAZO BROWN R

PHENO BLUE 2B

PHENO BRIGHT GREEN

PHENO BROWN MRS

PHENO BROWN RP

PHENO BROWN 3GXX

PHENO FAST RED $F$

PHENO NAVY BLUE

PHENO VIOLET N

POLAN BORDEAUX BS

POLAN DARK GREEN BS

POLAN RED FS

POLAN SCARLET $2 \mathrm{G}$

POLAN VIOLET RS

POLAN YELLOW 6G

POLAR RED $G$

POLAR RED GSUPRA

POLAR YELLOW $R$

POLOXAL BROWN 3GL

POLOXAL YELLOW RD

POLYCOR DARK GREEN S

POLYCOR RED GS

PONTACYL SCARLET R

PONTAMINE BLACK RRX

PONTAMINE BLUE BB

PONTAMINE BORDEAUX B

PONTAMINE BROWN

PONTAMINE BROWN BCW

PONTAMINE BROWN BT

PONTAMINE BROWN N3G

PONTAMINE BROWN RMR
PONTAMINE BROWN XR

PONTAMINE DEEP BLUE BH

PONTAMINE DIAZO BLACR BHSW

PONTAMINE DIAZO BROWN R

PONTAMINE FAST BROWN BRL

PONTAMINE FAST BROWN NP

PONTAMINE FAST RED F

PONTAMINE FAST RED FCB

PONTAMINE GARNET $R$

PONTAMINE GREEN BXN

PONTAMINE GREEN GXN

PONTAMINE GREEN $S$

PONTAMINE SCARLET B

PONTAMINE VIOLET $N$

PYRAZOL BLACK ER

PYRAZOL BLACR W

PYRAZOL BLUE 2BX

PYRAZOL BORDEAUX GL

PYRAZOL BROWN ADX

PYRAZOL BROWN D3Y

PYRAZOL BROWN MP

PYRAZOL BROWN MR

PYRAZOL BROWN PL

PYRAZOL BROWN TM

PYRAZOL BROWN TW

PYRAZOL BROWN 2R

PYRAZOL DARK RED BR, BRY, $R$

PYRAZOL FAST BROWN B

PYRAZOL FAST BROWN BRL

PYRAZOL GREEN BC

PYRAZOL GREEN BP

PYRAZOL GREEN F2G

PYRAZOL GREEN G

PYRAZOL GREEN GB

PYRAZOL GREEN 2B

PYRAZOL ORANGE RB

PYRAZOL RED BR

PYRAZOL RED C

PYRAZOLINE BROWN BRL

PYRAZOLON FAST ORANGE GN

RESIN FAST BLACK WP

RESOFIX BLUE C2RL

ROYCEPULP FAST ORANGE R

SANDOLAN MILLING YELLOW N-66

SANDOLAN PRINTING YELLOW PR

SANDOPEL DARK GREEN B

SATURN BROWN LBR

SELLA FAST RED C 
BENZIDINE-BASED DYES

(continued)

SHIKISO ACID ANTHRACENE RED G SHIRISO ACID ANTHRACENE RED 3BL SHIRISO ACID FAST YELLOW MR SHIRISO ACID RED PG SHIRISO DIRECT DARR GREEN B SHIKISO DIRECT SCARLET BX SHOWA DIRECT FAST BROWN GR SILR ORANGE R

SILR RED $G$

SILR RED 3B

SILR SCARLET G

SIRIUS SUPRA BROWN BRI

SIRIUS SUPRA BROWN BRS

SOLAMIDINE B

SOLAMINE LIGHT SCARLET B

SOLANTINE BROWN BRL

SOLAR BROWN PL

SOLAR MILLING RED 3B

SOLAR SCARLET BL

SOLEX BROWN R

SOLIUS LIGHT BROWN BRLL

SOLIUS LIGHT BROWN BRS

SOLIUS LIGHT SCARLET BNL SOLOPHENYL SCARLET BNL SOLUBILISED VAT BLUE 6

SOLUCONGO

SUGAI CONGO RED

SUGAI DIRECT BROWN $M$

SUGAI DIRECT ORANGE $R$

SULPAN YELLOW PR

SULFON RED J

SULFON SCARLET R

SULFON YELLOW PR

SULFONINE RED G

SULFONINE RED GN

SULFONINE RED GS

SULFONINE RED SG

SULFONINE YELLOW CSR

SULFONINE YELLOW PR

SULPHON YELLOW RS-CF

SULPHONOL RED PG

SUMILIGHT SUPRA BROWN BRS

SUMILIGHT SUPRA BROWN BRS FOR

SUMILIGHT SUPRA SCARLET BNS

SUMINOL BRILLIANT SCARLET DH

SUMINOL MILLING BRILLIANT YELLOW 5G

SUMINOL MILLING ORANGE R

SUMINOL MILLING RED PG
SUMINOL MILLING RED 3B

SUMINOL MILLING YELLOW MR

SUMINOL MILLING YELLOW RS

SUMINOL RED PG

SUMINOL YELLOW MR

SUMITOMO ACID ANTHRACENE RED 3 BL

SUMITOMO FAST SCARLET $G$

SUMITOMO MILLING YELLOW H5G

SUNCHROMINE FAST YELLOW RR

SUPERCHROME YELLOW GRN

SUPERNYLITE SCARLET G

SUPRANOL FAST SCARLET GN

SUPRANOL RED PG

SUPRANOL RED PG-CF

SUPRANOL SCARLET BN

SUPRANOL SCARLET GN

SUPRANOL SCARLET GS

SUPRANOL YELLOW R

SUPRANOL YELLOW RA

SUPRAZO BROWN BRL

SUPREXCEL BROWN BRL

SUPREXCEL SCARLET BNLL

SYMULON ACID FAST YELLOW MR

SYMULON ACID RED PG

SYMULON DIRECT BLACK BH

SYMULON DIRECT BORDEAUX NS

SYMULON DIRECT BROWN GR

SYNODIRECT BLUE 2B $100 \%$

SYNODIRECT ORANGE Y 100\%

SYNODIRECT RED 4B $100 \%$

TARAORA DIRECT ORANGE $R$

TARAORA DIRECT BROWN CB

TARDIREKT BROWN M

TARDIREKT GREEN B

TARDIREKT RED $R$

TELON FAST 'SCARLET $N$

TERTRACID MLLING RED AGE

TERTRACID MLLING RED A3B

TERTRACID MILLING RED $G$

TERTRACID MILLING YELLOW H5G

TERTRACID MILLING YELLOW $R$

TERTRACID MILLING YELLOW 3R

TERTRODIRECT BLACK BH

TERTRODIRECT BLACK BHS

TERTRODIRECT BLACK RW

TERTRODIRECT BLUE 2B

TERTRODIRECT BORDEAUX B

TERTRODIRECT BORDEAUX CG 
BENZIDINE-BASED DYES

(continued)

TERTRODIRECT BROWN B TERTRODIRECT BROWN CGN TERTRODIRECT BROWN G TERTRODIRECT BROWN MJ TERTRODIRECT BROWN OXP TERTRODIRECT BROWN TB TERTRODIRECT FAST BROWN BR TERTRODIRECT GREEN B TERTRODIRECT GREEN BG TERTRODIRECT GREEN G TERTRODIRECT LIGHT SCARLET BNL TERTRODIRECT ORANGE PG TERTRODIRECT PONCEAU B TERTRODIRECT RED C TERTRODIRECT RED F TERTRODIRECT VIOLET N TETRAMINE BROWN S TETRAMINE FAST BROWN BRDN EXTRA TETRAMINE FAST BROWN BRP TETRAMINE FAST BROWN BRS TETRAZO DEEP BLACK R TRIANTINE BROWN BRS TRIANTINE FAST BROWN OG TRIANTINE FAST BROWN OR TRIANTINE LIGHT BROWN BRS TRIANTINE LIGHT BROWN OG TRIAZOL BROWN B TRIAZOL FAST SCARLET B TRISULFON BROWN $M$ TRISULFON BROWN TW TRISULFON BROWN TWP TRISULFON BROWN 3R TRISULFON CONGO RED TRISULFON GARNET BR TRISULFON GARNET BRY TRISULFON VIOLET N TRISULPHONE BROWN B ULTRA FLAVINE NS UNION BORDEAUX BB UNION BROWN DR UNION DARR GREEN B UNION FAST NAVY BLUE DS UNION FAST RED 3B UNION FAST SCARLET B VEGENTINE FAST BROWN B VILMALUZ FAST BROWN BRS VILMAMIN BLACK RW VILMAMIN BLUE GS
VILMAMIN BORDEAUX B

VILMAMIN CONGO RED

VILMAMIN DARR BROWN B VILMAMIN DARR GREEN B VILMAMIN FAST RED $F$ VILMAMIN GREEN B VILMAMIN BROWN $M$ VILMANOL FAST RED $G$ VILMANOL FAST YELLOW R VILMANOL FAST YELLOW 5G VISCO GREEN $G$ VONDACEL BLACR RW VONDACEL BLUE 2B VONDACEL BORDEAUX B VONDACEL BROWN BN VONDACEL BROWN $G$ VONDACEL BROWN M VONDACEL BROWN S VONDACEL BROWN SP VONDACEL DARK BLUE BH VONDACEL GREEN B VONDACEL GREEN DB VONDACEL GREEN G VONDACEL ORANGE $P$ VONDACEL RED CL VONDACEL RED FN VONDAMOL BRILLIANT RED BG VONDAMOL BRILLIANT RED $G$ VONDAMOL FAST RED G VONDAMOL FAST YELLOW H5G WOOL SCARLET B

XYLENE MILLING RED G XYLENE MILLING RED R XYLENE MILLING RED 3BA XYLENE MILLING YELLOW SH XYLENE MILLING YELLOW 6G ZAMBESI DARR BLUE BH 


\section{O-TOLIDINE-BASED DYES}

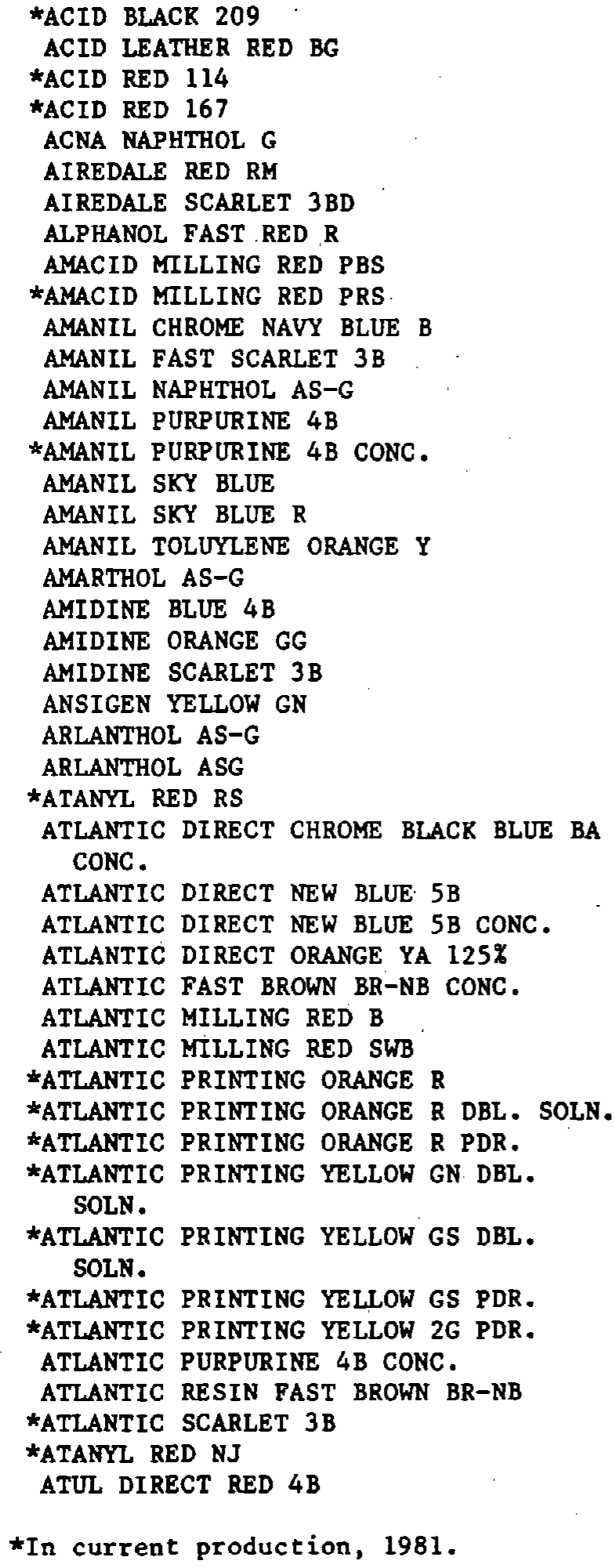

*In current production, 1981.

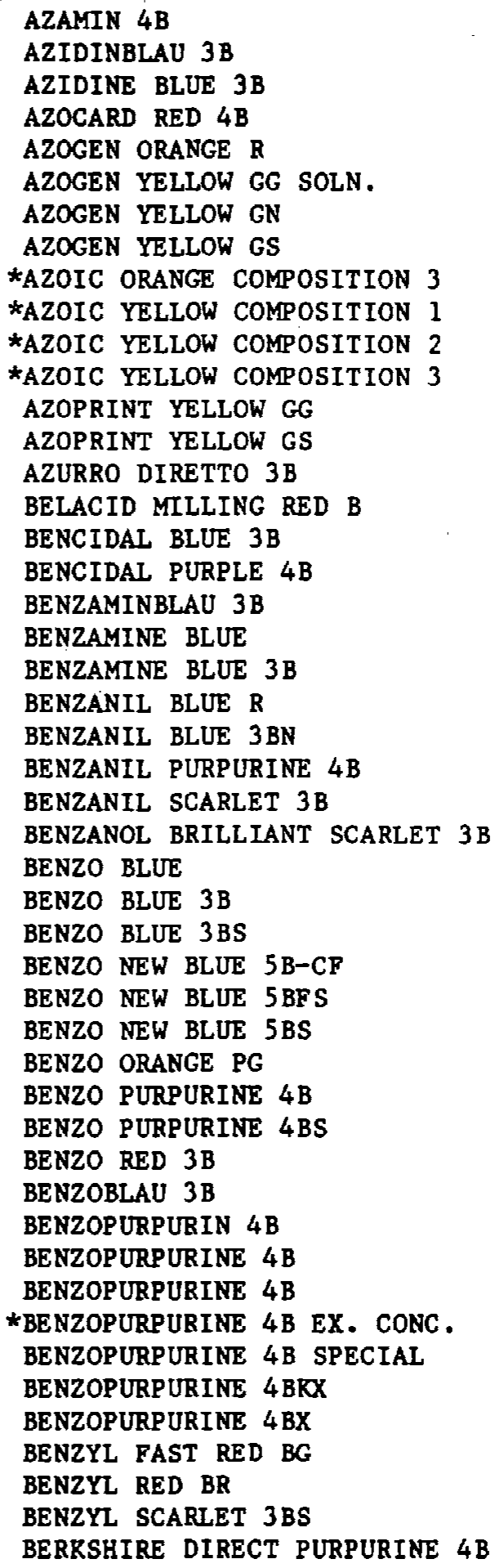


O-TOLIDINE-BASED DYES

(continued)

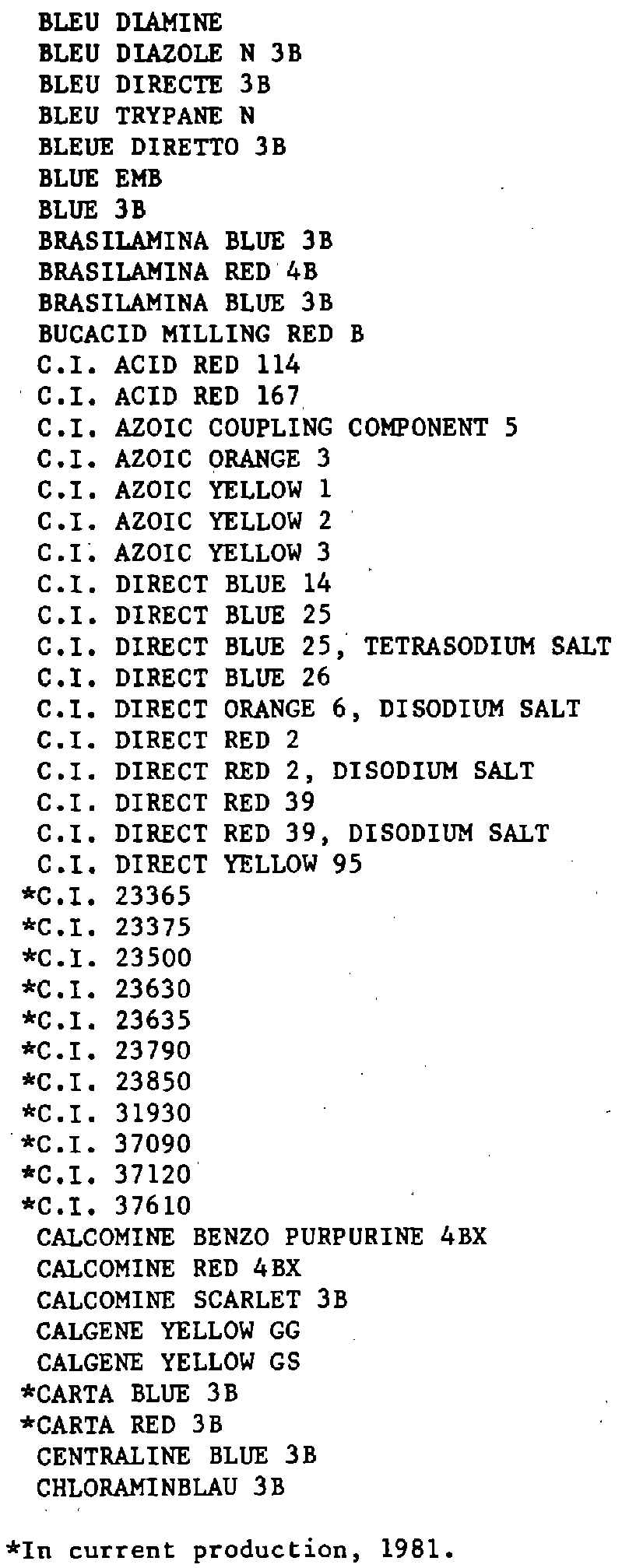

CHLORAMINE BLUE CHLORAMINE BLUE 3B CHLORAMINE NEW BLUE 5B CHLORAMINE RED 3B CHLORAZOL BLUE 3B

*CHROME LEATHER BLUE 3B CHROME LEATHER RED 4B CHROME LEATHER SCARLET 3BS CIBANAPHTHOL AG CITAZOLO YELLOW G CONGO BLUE CONGO BLUE 3B CONGOBLAU 3B COOMASSIE RED 2R COTTON RED 4B COTTON RED 4BS COTTON RED 4BS CONC. COTTON RED 4BS SUPRA CRESOTINE BLUE 3B *CUPROPHENYL YELLOW 3GL DAITO GROUNDER G DERMA BLUE 5B DIACETYLACE TOTOL IDIDE DIACOTTON BENZOPURPURINE 4B DIAMINBLAU 3B DIAMINE BLUE 3B DIAMINE PURPURINE 4B DIAMINE RED 4B DIAMINE SCARLET $3 \mathrm{BA}-\mathrm{CF}$ DIAMINEBLUE DIANIL BLUE DIANIL BLUE B DIANIL BLUE H3G DIANIL RED 4B DIANILBLAU DIANILBLAU H3G DIAPHTAMINE BLUE TH DIAPHTAMINE FAST SCARLET 3B DIAPHTAMINE PURPURINE 4B DIAZAMINE ORANGE GG DIAZAMINE PURPURINE 4B DIAZINE BLUE 3B DIAZINE RED 4B *DIAZO BLACK BH-NB DIAZOL BLUE 3B DIAZOL PURE BLUE BR DIAZOL PURE BLUE BRA DIAZOL PURPURINE 4B 
O-TOLIDINE BASED DYES

DIAZOL SCARLET 3B

DIMACIDE RED F-RB

DIMACIDE RED F-RBA

DIPHENYL BLUE 3B

*DIPHENYL BLUE 3B CONC.

DIPHENYL BLUE 3B EX. CONC.

*DIPHENYL BRILLIANT BLUE 5B

*DIPHENYL GREEN BBN

DIPHENYL ORANGE GG

DIPHENYL RED 3BS

DIPHENYL RED 4B

*DIPHENYL RED 4BS

DIPHENYL RED 4BS SUPRA

DIPHENYL SCARLET $3 B S$

DIRECT BLUE D3B

DIRECT BLUE FFN

DIRECT BLUE H3G

DIRECT BLUE M3B

DIRECT BLUE 26

*DIRECT BLUE 2B-NB

DIRECT BLUE $3 \mathrm{~B}$

*DIRECT BLUE 3B CONC.

DIRECT BLUE $3 \mathrm{BX}$

DIRECT BLUE $5 B$

DIRECT BRILLIANT BLUE BC

DIRECT BRILLIANT BLUE $5 \mathrm{BC}$

*DIRECT BRILLIANT BLUE 5BC CONC.

\#DIRECT BROWN BRL-NB $200 \%$

*DIRECT BROWN GG-NB

*DIRECT BROWN M-NB

*DIRECT BROWN US-NB

*DIRECT BROWN 230

*DIRECT CHROME BLUE BLACK B. EX. CONC. DIRECT CHROME DARK BLUE 2B

*DIRECT FAST BROWN BCW-NB

*DIRECT FAST BROWN BP-NB CONC.

*DIRECT FAST BROWN BR-NB CONC.

\#DIRECT FAST BROWN BRLT

DIRECT FAST BROWN 3RLT

*DIRECT FAST ORANGE Y $125 \%$

DIRECT FAST RED 3B

DIRECT FAST SCARLET 3B

*DIRECT NEW BLUE 5B

*DIRECT NEW BLUE 5B CONC.

DIRECT ORANGE G

DIRECT ORANGE T

DIRECT ORANGE 6

DIRECT PURE BLUE 5B

*In current production, 1981.

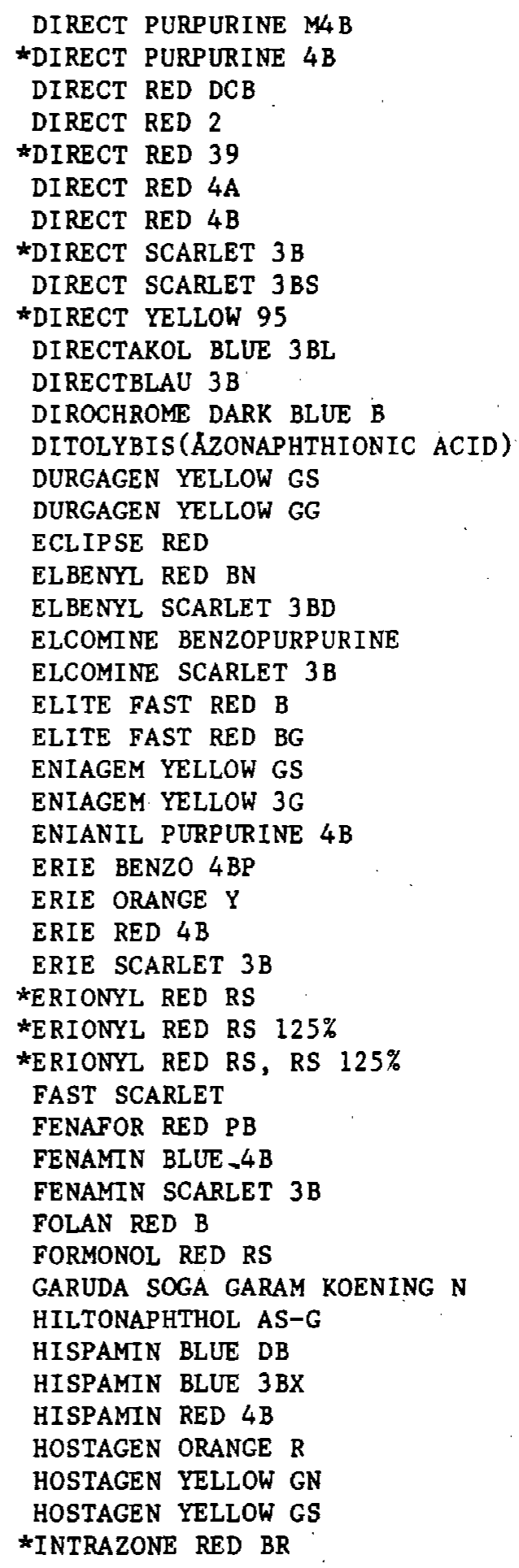


O-TOLIDINE BASED DYES

(continued)

RAMBOFAST YELLOW GGH

RAMBOGEN ORANGE R

RAMBOTHOL AS-G

RAMBOTHOL ASG

RAYAKU BENZOPURPURINE 4B

RAYAKU DIRECT SCARLET 3B

RAYANOL MILLING RED RS

RIWA GROUNDER G

ROROSTAN RED PRS

LANAPERL FAST RED R

LEATHER FAST RED B

*LEVANOL FAST RED GG NEW

MIDLON RED PRS

MILLING FAST RED B

MILLING FAST RED $R$

*MILLING RED B

MILLING RED BB

*MILLING RED G-NB

MILLING RED PBX

MILLING RED R

MILLING RED RB

MILLING RED RBA

*MILLING RED SWB

*MILLING RED SWB CONC. MITSUI BENZOPURPURINE 4BX MITSUI DIRECT SCARLET $3 \mathrm{BX}$ MITSUI NAPHTHOZOL $G$

NAILAMIDE RED $S-R$

NAPHTAMINE BLUE 2B

NAPHTAMINE BLUE $3 \mathrm{BX}$

NAPHTANILIDE G

NAPHTAZOL I

NAPHTAZOL J

NAPHTHAMINBLAU $3 \mathrm{BX}$

NAPHTHAMINE BLUE $3 \mathrm{BX}$

NAPHTHANIL $G$

NAPHTHOIDE $G$

NAPHTHOL AS-G

NAPHTHOL AS-G DISPERSIBLE

NAPHTHOL AS-G SOLN.

NAPHTHOL AS-G SUPRA

NAPHTHOL ASG

NAPHTHOL ASG 20\% SOLN.

NAPHTHYLAMINE BLUE

NAPHTO $G$

NAPHTOELAN G

NAPHTOL AS-G

NAPHTOL AS-G SUPRA
*NEUTRAZOIC GOLDEN YELLOW $R$

*NEUTRAZOIC GOLDEN YELLOW R PDR. NEUTRAZOIC ORANGE R PDR.

* NEUTRAZOIC YELLOW GS

*NEUTRAZOIC YELLOW GS PDR.

* NEUTRAZOIC Yellow 2G

*NEUTRAZOIC YELLOW 2G PDR.

NIAGARA BLUE

NIAGARA BLUE - 3B

NIAGARA BLUE 5B

NIAGARA CHROME BLUE BLACR B

NIKKAGEN YELLOW $G$

NIPPON NEW BLUE 5BS

NIPPON ORANGE GG

NOVANYL RED $F-R$

NYLOMINE RED C-2R

*NYLON FAST RED RM

NYLONSAN RED F-RS

*NYLOSAN RED F-BR

NYLOSAN RED F-RS

OPTANOL RED RS

ORCOACID MILLING RED RS

ORCOACID MILLING RED RS 125\%

ORCOMINE SCARLET 3B

*PADAZOIC GOLDEN YELLOW RLL PDR.

*PADAZOIC ORANGE GR PDR.

*PADAZOIC YELLOW G PDR.

PAPER BLUE 1

PAPER RED 4BS

*PAPER RED 4BS CONC.

PAPER SCARLET 3BP

PARAMINE BLUE $3 B$

PARAMINE FAST SCARLET 3B

PARKIBLEU

PARKIPAN

PENETRATING BLACK AM-NB

PERGASIZE RED G

*PERGASOL BLUE 3B CONC.

*PERGASOL BRILLIANT BLUE 5B

*PERGASOL GREEN BBN

PERGASOL RED 3BS

*PERGASOL RED 4BS CONC.

PHARMASOL GOLDEN YELLOW N

PHARMASOL ORANGE R

PHARMASOL YELLOW GN

PHARMOL GOLDEN YELLOW N

PHARMOL ORANGE $\mathbf{R}$

PHARMOL YELLOW GN

*In current production, 1981. 
O-TOLIDINE BASED DYES

(continued)

PHENAMINE BLUE 5B

PHENAMINE PURPURINE 4B

PHENAMINE SCARLET 3B

PHENO FAST SCARLET 4B

PIPHENYL GREEN BBN

POLAN RED B

*POLAR RED B

POLAR RED B CONC.

POLAR RED RS

*POLAR RED RS CONC. $125 \%$

POLOGEN YELLOW GN

POLYDOGEN ORANGE R

POLYDOGEN YELLOW G

POLYDOGEN YELLOW GG

POLYDOGEN YELLOW NK-G

PONTAMINE BLUE $3 \mathrm{BX}$

PONTAMINE BLUE 5B

PONTAMINE SCARLET 3B

PRINTING ORANGE LR

PRINTING ORANGE $R$

PRINTING ORANGE R SOLN.

PRINTING YELLOW GA

PRINTING YELLOW GN

PRINTING YELLOW GS

PRINTING YELLOW $2 G$

PROMPT PRINTING YELLOW GGH

PURPURIN 4B

PURPURINE 4B

PYAZOL NEW BLUE

*PYRAZOL BLACR BF

*PYRAZOL BLUE 3B

*PYRAZOL DARK GREEN 3B

\#PYRAZOL NEW BLUE 5B

*PYRAZOL RED 3B

PYROTROPBLAU

RAPID FAST YELLOW GGH

RAPIDOGEN GOLDEN YELLOW R

RAPIDOGEN YELLOW GS

RAPRICOL LEMON YELLOW 3G

RAPRICOL YELLOW GGH

RAPRIGEN YELLOW GG

RAPRIGEN YELLOW GS

RENOLBLAU 3B

ROMAGENE YELLOW GS

RONAGEN ORANGE $R$

RONAGEN YELLOW G

RONAGEN YELLOW GS

RONAGEN YELLOW $2 G$

\author{
SANATOL AS-G \\ SANATOL $G$ \\ SANDOLAN RED N-RS \\ *SANDOLAN RED N-3B \\ *SELLA FAST BLACK FC \\ SELLA FAST RED RS \\ SELLA FAST RED $V$ \\ SHIKISO DIRECT SCARLET 3B \\ SINAGEN YELLOW $G$ \\ SINAGEN YELLOW $2 G$ \\ SOLOPHENYL ORANGE ARL \\ SOLUNAPTOL YL \\ STABAGENE YELLOW 2G \\ SULPHONOL RED R \\ SULTAN RED 4B \\ SUMIRA FAST YELLOW GGH \\ SUMINOL MILLING RED RS \\ *SUPERNYLITE SCARLET B \\ SUPRANOL FAST RED GG \\ SUPRANOL RED PBX \\ SUPRANOL RED PBX-CF \\ SUPRANOL RED R \\ TELON FAST RED GG \\ * TELON FAST RED GG NEW \\ TERTRACID MILLING RED B \\ TERTRODIRECT RED 4B \\ THIUGEN YELLOW G \\ THIUGEN YELLOW GG \\ TOLUYLENE ORANGE $G$ \\ TOLUYLENE ORANGE GR \\ TRIANOL DIRECT BLUE 3B \\ TRIAZOL FAST SCARLET 3B \\ TRIAZOLBLAU 3BX \\ TRYPAN BLUE \\ TRYPAN BLUE BPC \\ TRYPAN BLUE SODIUM SALT \\ TRYPANBLAU \\ TRYPANE BLUE \\ TULAGENE YELLOW 2G \\ TULATHOL AS-G \\ ULTRAZOL $G$ \\ UNION FAST SCARLET 3B \\ VILMAMIN PURPURINE 4B \\ VILMANOL FAST RED R \\ VONDAMOL FAST RED RS \\ WINOFAST YELLOW GGH \\ WINSOGEN YELLOW GS \\ WOOL SCARLET 3B
}

*In current production, 1981. 
O-DIANISIDINE-BASED DYES

ACCO NAF-SOL AS-BR

ACCO NAPHTHOL AS-BR

AIREDALE BLUE $D$

AIREDALE BLUE FFD

AIREDALE BLUE NGLD

AIREDALE BLUE RWD

AIZEN DIRECT SKY BLUE 5BH

* AMAFAST BLUE 16 BLL

* \#AMAFAST BLUE 3GAV CONC.

\#AMAFAST BLUE 3RLP LIQ.

\#AMAFAST BLUE 3RLP PST.

*\#AMAFAST BLUE 7RLL

*AMAFAST BLUE ARF

* AMAFAST BOND BLUE 10 GLP CONC.

*\#AMAFAST BOND BLUE 10 GLP LIQ.

AMANIL AZURINE $G$

AMANIL BLUE RW

AMANIL BLUE 2BX

AMANIL NAPHTHOL AS-BR

AMANIL SKY BLUE

*AMANIL SKY BLUE FF

*AMANIL SKY BLUE M LIQUID

*aMANIL SKY BLUE 6B

AMANIL SUPRA BLUE 9GL

AMARTHOL AS-BR

AMARTHOL FAST BLUE B BASE

AMIDINE SKY BLUE 5B EX.

ATLANTIC AZURINE G

*atLANTIC AZURINE G CONC.

ATLANTIC BLUE RW

ATLANTIC DIAZO FAST BLUE MP

ATLANTIC DIRECT BLUE R CONC.

ATLANTIC DIRECT BLUE RW

*ATLANTIC DIRECT BLUE RW $100 \%$

*ATLANTIC DIRECT BLUE 2BNB

ATLANTIC DIRECT BOND BLUE B

ATLANTIC DIRECT SKY BLUE M LIQ. ATLANTIC DIRECT SKY BLUE 6B CONC. ATLANTIC DIRECT SKY BLUE 6B EX. 200\%

ATLANTIC DIRECT SKY BLUE 6B EX. 300\%

*ATLANTIC PRINTING BLACK FOR PDR.

*ATLANTIC PRINTING BLACR 2B PDR.

*ATLANTIC PRINTING BLACK 3G PDR.

*ATLANTIC PRINTING BLUE D PDR.

*atlantiC PRINTING BLUE D-BC PDR.

*ATLANTIC PRINTING BLUE GB PDR.

*ATLANTIC PRINTING BROWN BR PDR.
*ATLANTIC PRINTING BROWN GGN PDR. ATLANTIC PEINTING NAVY BLUE IR PDR. * ATLANTIC RESIN FAST BLUE ARL * ATLANTIr RESIN FAST BLUE BFL * ATLANTIC RESIN FAST BLUE BLA 150\% * ATIANTIC RESIN FAST BLUE BLC * ATLANTIC RESIN FAST BLUE BRN * ATLANTIC RESIN FAST BLUE FFBL * ATLANTIC RESIN FAST BLUE LBGL * ATLANTIC RESIN. FAST BLUE LLGG * ATIAANTIC RESIN FAST BLUE LLU * ATLANTIC RESIN FAST BLUE LLU 200\% * ATLANTIC RESIN FAST BLUE LLUG * ATLANTIC RESIN FAST BLUE RLX * ATLANTIC RESIN FAST BLUE UGLL * ATLANTIC RESIN FAST BLUE 16BLL CONC * ATLANTIC RESIN FAST BLUE 2RLL * \#ATLANTIC RESIN FAST BLUE 3GLL * ATLANTIC RESIN FAST BLUE 5GLL * ATLANTIC RESIN FAST BLUE 6GRS * ATLANTIC RESIN FAST BLUE 7GUL * ATLANTIC RESIN FAST BLUE 8BGI 200\% * ATLANTIC RESIN FAST BLUE 8GLN * ATLANTIC RESIN FAST BLUE 8GUM * ATLANTIC RESIN FAST BLUE 9GLR *ATLANTIC RESIN FAST GREY LVL ATLANTIC SKY BLUE A

*ATLANTIC SKY BLUE A EX. CONC. ATLANTIC SKY BLUE A SUPER CONC. 12: *ATLANTIC SKY BLUE FF EX. CONC. ATLANTIC SKY BLUE FF ATLANTIC SKY BLUE 6B

*aTLANTIC SKY BLUE 6B CONC. *ATLANTIC STABLE BLUE B PDR. ATUL DIRECT BLUE $G$ ATUL DIRECT BLUE $X$ ATU DIRECT SKY BLUE ATUL DIRECT SKY BLUE FB AZINE BRILIIANT BLUE RW AZINE BRILLIANT BLUE 6B AZINE COPPER BLUE 2B AZINE SKY BLUE 5B AZOANTHRENE JET BLACK R EX. CONC. AZOANTHRENE ROYAL BLUE L AZOCARD BLUE 6B AZOENE FAST BLUE B BASE AZOENE FAST BLUE B SALT AZOFORM BLUE FO

*In current production, 1981.

\#Metallized dye 


\section{O-DIANISIDINE-BASED DYES}

(continued)

AZOGEN BLUE D

AZOGEN BLUE GN

AZOGENE FAST BLUE B

*AZOIC BLACR COMPOSITION 4

*AZOIC BLUE COMPOSITION 2

*AZOIC BLUE COMPOSITION 3

*AZOIC COUPLING COMPONENT 3

*AZOIC DIAZO COMPONENT 48

AZONENE FAST BLUE B SALT

AZOTOL DA

BELAMINE AZURINE G

BELAMINE SKY BLUE A

BELAMINE SKY BLUE FF

BENZANIL AZURINE G

BENZANIL BLUE RH

BENZANIL FAST COPPER BLACR $R$

BENZANIL FAST COPPER NAVY BLUE $R$

BENZANIL SKY BLUE

BENZANIL SKY BLUE FF

BENZANIL SUPRA BLUE FBGL

BENZANIL SUPRA BLUE NLG

BENZANIL SUPRA BLUE 2GN

BENZANIL SUPRA BLUE 2GNP

BENZANIL SUPRA BLUE 2RLL

BENZANOL AZURINE G

BENZANOL BLUE RW

BENZO AZURINE G

BENZO AZURINE GA-CF

BENZO AZURINE GS

\#BENZO BLUE RWA

BENZO BLUE RWS

BENZO BRILLIANT BLUE 6BS

\#BENZO COPPER BLUE CVBS

BENZO CUPROL BLACR RLW

*BENZOCUPROL NAVY BLUE RLW 200

\#BENZO CUPROL NAVY BLUE RLW

BENZO FAST COPPER BLACK RLW

\#BENZO FAST COPPER NAVY BLUE RLW

BENZO SKY BLUE

BENZO SKY BLUE A-CF

BENZO SKY BLUE $S$

BENZOAZURIN

BLUE BASE NB

*BLUE M LIQUID

* BOND BLUE B

* BOND BLUE WD

BRASILAMINA BLUE $G$

BRASILAMINA BLUE RW
BRASILAMINA COPPER BLUE R

BRASILAMINA SKY BLUE 6B

BRILLIANT BENZO BLUE 6BA-CF

C.I. AZOIC BLACK 4

C.I. AZOIC BLUE 2

C.I. AZOIC BLUE 3

C.I. AZOIC COUPLING COMPONENT 3

C.I. DIRECT BLACK 114

C.I. DIRECT BLACK 91

C.I. DIRECT BLACR 91, TRISODIUM SALT

* \#C.I. DIRECT BLACK 118

*C.I. DIRECT BLACK 167

*C.I. DIRECT BLUE 1

C.I. DIRECT BLUE 1, TETRASODIUM SALT

*\#C.I. DIRECT BLUE 100

*C.I. DIRECT BLUE 15

C.I. DIRECT BLUE 15, TETRASODIUM SALT

*C.I. DIRECT BLUE 22

*C.T. DIRECT BLUE 151

C.I. DIRECT BLUE 151, DISODIUM SALT

*C.I. DIRECT BLUE 156

*C.I. DIRECT BLUE 160

*C.I. DIRECT BLUE 191

* $\#$ C.I. DIRECT BLUE 218

*C.I. DIRECT BLUE 269

C.I. DIRECT BLUE 22

C.I. DIRECT BLUE 22 , DISODIUM SALT

* C.I. DIRECT BLUE 224

C.I. DIRECT BLUE 225

C.I. DIRECT BLUE 229

*C.I. DIRECT BLUE 267

C.I. DIRECT BLUE 269

*C.I. DIRECT BLUE 76

* \#.I. DIRECT BLUE 76, TETRASODIUM SALT

* C.I. DIRECT BLUE 77

*C.I. DIRECT BLUE 8

C.I. DIRECT BLUE 8 , DISODIUN SALT

* $*$ C.I. DIRECT BLUE 80

* C.I. DIRECT BLUE 90

* *C.I. DIRECT BLUE 98

*C.I. DIRECT BROWN 200

*C.I. DIRECT VIOLET 93

*C.I. DIRECT YELLOW 68

*\#C.I. 23155

*C.I. 24140

* C.I. 24175

*C.I. 24280

C.I. 24315

*In current production, 1981.

\#Metallized dye 
O-DIANISIDIHE-BASED DYES

(continued)

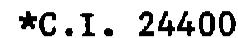

太非C.I. 24401

$\star C . I$. 24410

* C.I. 24411

*C.I. 30400

*C.I. 37235

*C.I. 37575

CALCODUR BLUE 6GFL

CALCODUR RESIN FAST BLUE 6G

CALCOMINE AZURINE BT

CALCOMINE SKY BLUE FF

*CALCOMINE SKY BLUE 6BX CONC.

* *alcarta BLUE RUL

* CARTA BLUE VP

* \#非CARTA GREY 3LBN

*CARTA SKY BLUE 2F

CARTASOL BLUE VP

*CARTASOL BLUE 2GF

* CARTASOL BLUE 3RF

* CARTASOL BLUE 4GF

CHICAGO BLUE RW

CHICAGO BLUE 6B

CHICAGO SKY BLUE 6B

CHLORAMINE BLUE BT

CHLORAMINE CHROME BLUE 2GLN

CHLORAMINE SKY BLUE A

CHLORAMINE SKY BLUE FF

CHLORAMINE SKY BLUE 4B

\#CHLORANTINE FAST BLUE A2GLL

\#CHLORANTINE FAST BLUE BLL

\#CHLORANTINE FAST BLUE B5GL

\#CHLORANTINE FAST BLUE 2RLL

非CHLORANTINE FAST BLUE 7GL

\#CHLORANTINE FAST BLUE 7GLL

CHLORAZOL AZURINE

CHLORAZOL AZURINE G

CHLORAZOL BLUE RW

CHLORAZOL COPPER BLUE B

CHLORAZOL SKY BLUE FF

CHROME LEATHER BLUE BT

CHROME LEATHER PURE BLUE

CHROME LEATHER SKY BLUE GS

COPPER BLUE $G$

COTTON BLUE CVB

CRESOTINE BLUE 6B

CRESOTINE PURE BLUE

CROMOCORIUN BLUE R

CUPRODIAZOL LIGHT NAVY RL

$\star$ In current production, 1981 .

非 Metallized dye
CUPRODIAZOL LIGHT BLACR RI CUPRODIAZOL LIGHT NAVY RL CUPRODIRECT BLUE CVS

*CUPROFIX BLACR C-RL CUPROFIX BLACK CRL

CUPROFIX BLUE FGL

CUPROFIX BLUE LUL

CUPROFIX BLUE 2GL

CUPROFIX DARK BROWN 3LB

CUPROFIX GREY 3LBN

CUPROFIX LIGHT BLUE 2RL

CUPROFIX NAVY BLUE CGBL

WCUPROFIX NAVY C-GRL

CUPROFIX PRINTING BLUE FGL

CUPROFIX PRINTING BLUE 2GL

CUPROFIX PRINTING GREY 3LBN

CUPROFIX YELLOW CZRL

¿CUPROPHENYL BLACK BWL

CUPROPHENYL BLACR RL

WCUPROPHENYL BLACK RL 200\%

*CUPROPHENYL NAVY BLUE BL

*CUPROPHENYL NAVY BLUE RL

CUPROPHENYL NAVY BLUE RL $200 \%$

*CUPROPHENYL VIOLET 3RL

CUPROPHENYL YELLOH RL

*CUPROPHENYL YELLOW RL EXTRA

CUTAMIN BLUE CR

CYCLOFAST BOND BLUE B

CYCLOFAST BOND BLUE B LIQ.

DERMA BLUE R

DERMA FAST BLUE GREY W-3BL

DERKAFIX YELLOW 2F

DIACOTTON AZURINE G

DIACOTTON BRILIIANT BLUE RW

DIACOTTON COPPER BLUE BB

DIACOTTON SKY BLUE 5B

DIACOTTON SKY BLUE 6B

DIAMINE AZORINE G

DIAMINE BLUE RWS

DIAMINE BLUE 6B

DIAMINE SRY BLUE

DIAMINERAL BLUE CVB

DIANIL AZURINE $G$

DLAPHTAMINE AZURINE G

DIAPHTAMINE BLUE BS

DIAPHTAMINE BLUE RW

DIAPHTAMINE COPPER BLUE FO

DIAPHTAMINE LIGHT BLUE FBGL 
O-DIANISIDINE-BASED DYES

(continued)

DIAPHTAMINE PURE BLUE

DIATO BLUE BASE B

DIAZAMINE BLUE B

DIAZINE SKY BLUE FF

DIAZO FAST BLUE MP

*非DIAZO FAST BLUE MP, MP CONC.

DIAZOL BLUE J

DIAZOL BLUE RW

\#DIAZOL BLUE 3JLNA

DIAZOL LIGHT BLUE 2RL

DIAZOL LIGHT BLUE 3JLN

DIAZOL LIGHT BLUE $7 \mathrm{JL}$

\#DIAZOL LIGHT BLUE 7JL U.C.

DIAZOL LIGHT BLUE $7 \mathrm{JL}$ ULTRA CONC.

DIAZOL LIGHT BLUE 7JLA

DIAZOL PURE BLUE 4B

DIAZOL PURE BLUE 6B

DIAZOPHENYL BLUE B

DIPHENYL BLUE BT

DIPHENYL BLUE G

DIPHENYL BRILLIANT BLUE

DIPHENYL BRILLIANT BLUE FF

*DIPHENYL BRILLIANT BLUE FF SUPRA

DIPHENYL SKY BLUE 6B

*DIRECT AZURINE G

*DIRECT AZURINE G CONC.

DIRECT AZURINE MG

DIRECT BLACK 91

DIRECT BLACR 114

* DIRECT BLACR 118

DIRECT BLUE BR

DIRECT BLUE BT

DIRECT BLUE CV

DIRECT BLUE FF

DIRECT BLUE FFN

DIRECT BLUE $G$

DIRECT BLUE HH

DIRECT BLUE MRW

*\#DIRECT BLUE R 100\%, R. CONC. DIRECT BLUE RW

*DIRECT BLUE RW CONC. $200 \%$

DIRECT BLUE RWN

DIRECT BLUE 1

DIRECT BLUE 10G

*\#DIRECT BLUE 100

DIRECT BLUE 15

DIRECT BLUE 156

DIRECT BLUE 160
*非DIRECT BLUE 191（S)

*非DIRECT BLUE 218

*非DIRECT BLUE 218/224（S）

DIRECT BLUE 22

*非DIRECT BLUE 224

DIRECT BLUE 269

DIRECT BLUE 6B

DIRECT BLUE 6BS

*非DIRECT BLUE 76

DIRECT BLUE 8

DIRECT BLUE 80

*非DIRECT BLUE 90

DIRECT BLUE 98

DIRECT BOND BLUE BP

DIRECT BRIGHT BLUE

DIRECT BRILLIANT BLUE FF

DIRECT BRILLIANT BLUE MFF

DIRECT BRILLIANT SKY BLUE 6B

*DIRECT BRILLIANT SKY BLUE 6B EX. CONC.

*\#DIRECT BROWN 200

DIRECT COPPER BLUE A

DIRECT COPPER BLUE B

非DIRECT FAST NAVY BRN

DIRECT LIGHTFAST BLUE KU

DIRECT PURE BLUE

DIRECT PURE BLUE FF

DIRECT PURE BLUE $M$

DIRECT PURE BLUE 6B

DIRECT PURE SKY BLUE

DIRECT SKY BLUE

DIRECT SKY BLUE A

*DIRECT SRY BLUE A SUPRA CONC. $125 \%$

DIRECT SKY BLUE FF

*DIRECT SKY BLUE FF EX. $200 \%$

*DIRECT SKY BLUE FF EX. $300 \%$

DIRECT SKY BLUE GREEN SHADE

DIRECT SKY BLUE GS

DIRECT SKY BLUE 5B

DIRECT SKY BLUE 6B

*DIRECT SKY BLUE 6B CONC.

*DIRECT SKY BLUE 6B EX. 200\%

*DIRECT SKY BLUE 6B EX. CONC. 300\%

DIRECT SKY BLUE 6BS

DIRECT VIOLET 93

DIRECT YELLOW 68

\#DURAZOL BLUE $2 \mathrm{GN}$

DURAZOL BLUE 2GNP

*In current production, 1981.

\# Metallized dye 
O-DIANISIDINE-BASED DYES

(continued)

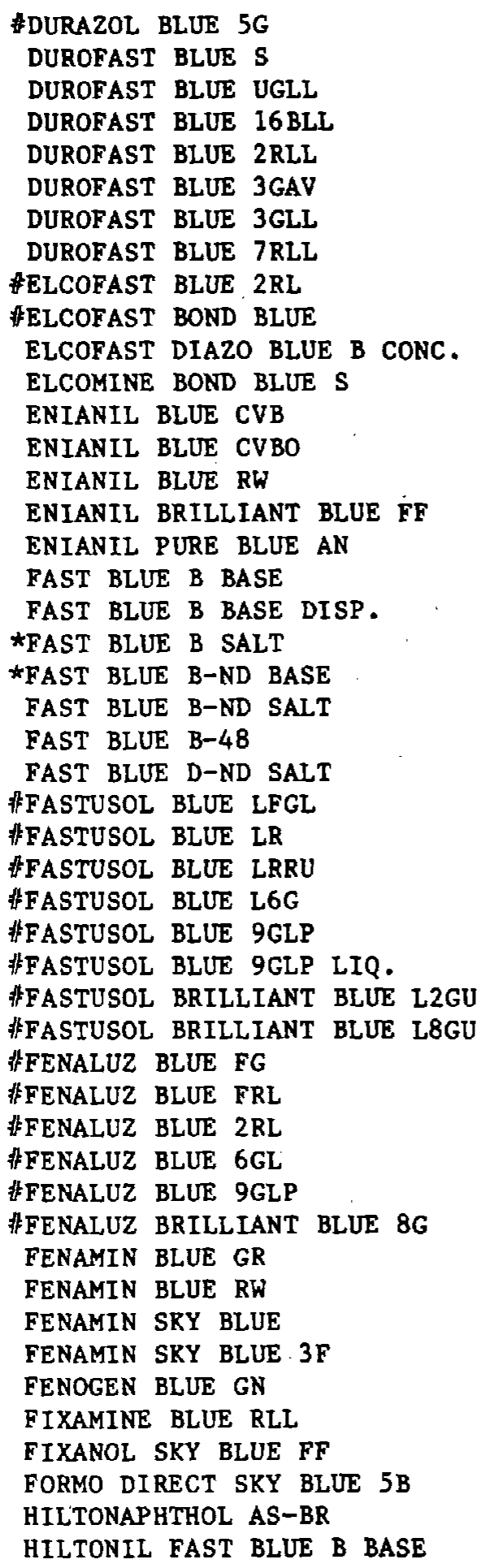

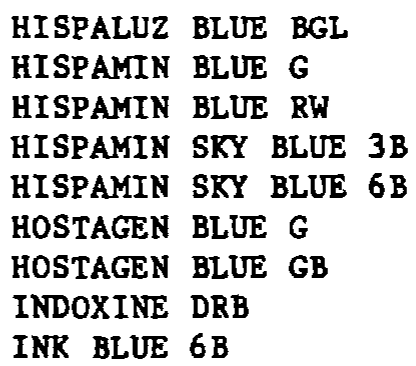


O-DIANISIDINE-BASED DYES

(cont inued)

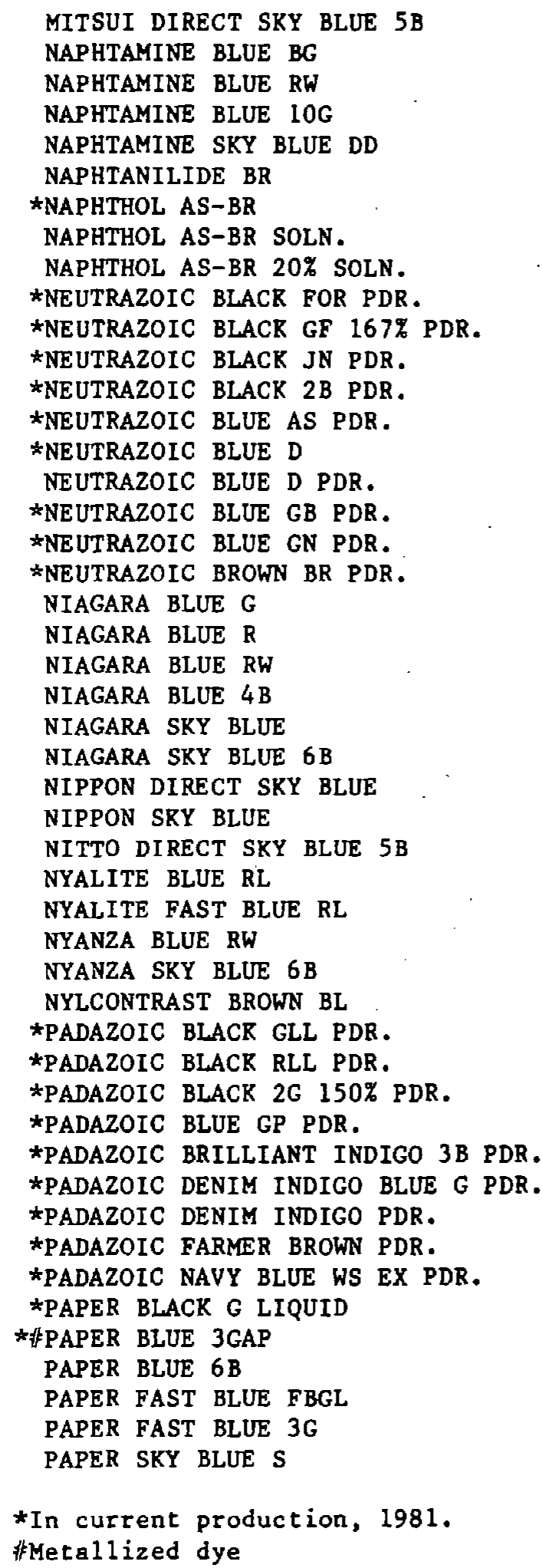

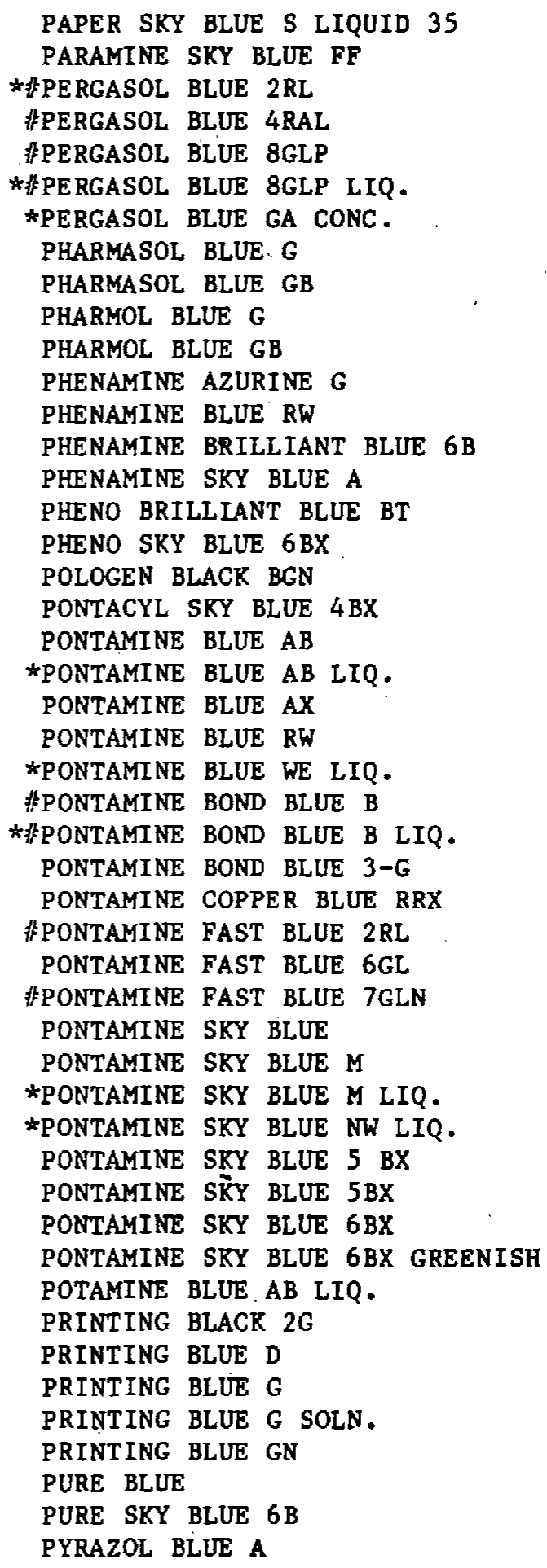


O-DIANISIDINE-BASED DYES

(continued)

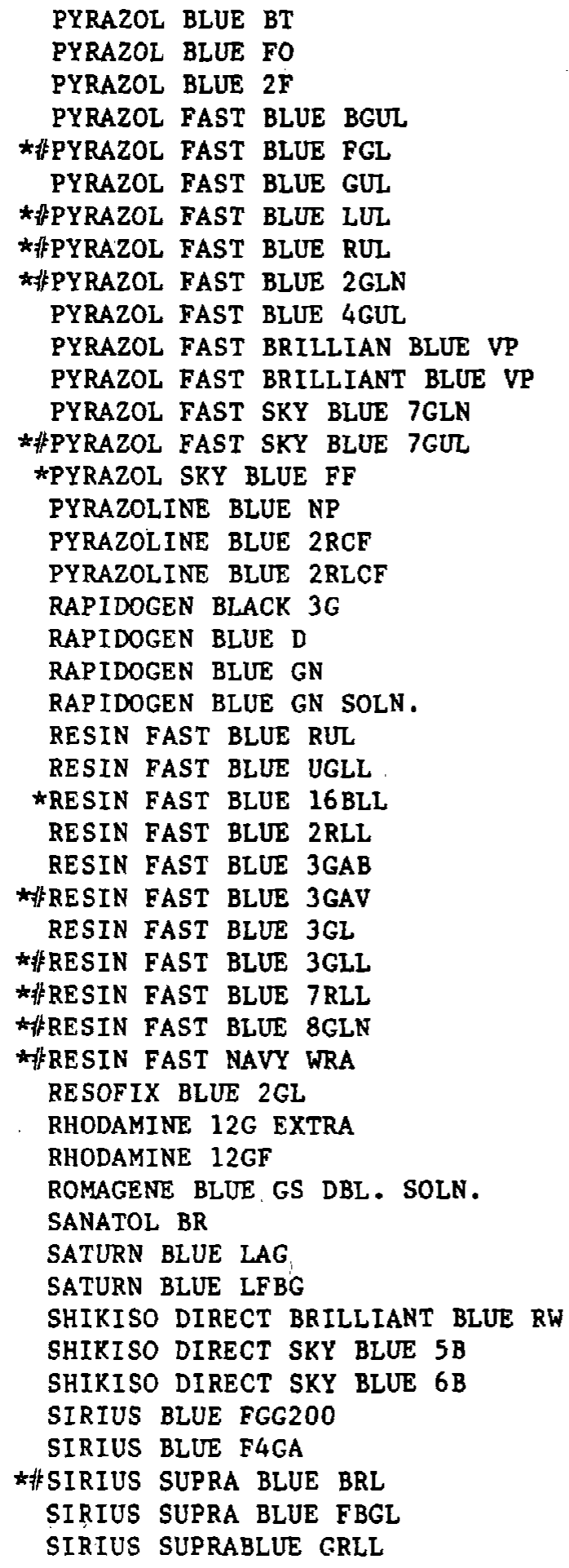

*In current production, 1981 .
\#SIRIUS SUPRA BLUE 2RL SIRIUS SUPRA BLUE 4G \#SIRIUS SUPRA BLUE 5G SKY BLUE FF

SKY BLUE 4B

SKY BLUE 5B

SRY BLUE 6B

\#SOLANTINE BLUE GLFV \#SOLANTINE BLUE SFRL \#SOLANTINE BLUE 10GL \#SOLANTINE BLUE 6GRS \#SOLANTINE BLUE 8GL SOLAR BLUE FGL SOLAR BLUE 2GLN SOLAR BLUE 2RL SOLAR BLUE 4GL SOLAR DARK BROWN 3LB SOLAR GREY 3LBN SOLEX BLUE FBGL SOLEX BLUE RL SOLIUS LIGHT BLUE FBGL SOLIUS LIGHT BLUE $7 \mathrm{GL}$ \#SOLOPHENYL BLUE A4RL * \$ SOLOPHENYL BLUE RBL *非SOLOPHENYL BLUE 2RL \#SOLOPHENYL BLUE 3GL \#SOLOPHENYL BLUE 6GL *非SOLOPHENYL BLUE 8GL * F SOLOPHENYL BLUE 8GLP LIQ. *SPECIAL BLACK G LIQ. * SPECIAL bLUE AB LIQ. * SPECIAL SKY bLUE M STABLE BLUE B BASE SUMILIGHT SUPRA BLUE FBGL SUMILIGHT SUPRA BLUE FGL *\#SUPERLITEFAST BLUE RL * SUPERLITEFAST BLUE GL * SUPERLITEFAST BLUE RLE SUPERLITEFAST BLUE RLF * SUPERLITEFAST BLUE WB *\#SUPERLITEFAST BLUE 3GLST * \$SUPERLITEFAST BLUE 8GLN * SUPERLITEFAST BLUE BGUL *非SUPERLITEFAST BRILLIANT BLUE 16BLL \#SUPERLITEFAST BRILLIANT BLUE 3GLST \#SUPERLITEFAST GL *非SUPERLITEFAST GREY LVL *非SUPERLITEFAST RUBINE WLKS 
O-DIANISIDINE-BASED DYES

(continued)

TARDIREKT BLUE 6B

TERTRODIRECT BLUE AG

TERTRODIRECT BLUE CVB

TERTRODIRECT BLUE $F$

TERTRODIRECT BLUE FF

TERTRODIRECT BLUE RW

TERTRODIRECT FAST YELLOW 3RS

TETRAMINE LIGHT BLUE FPB

TRIANTINE LIGHT YELLOW RR

TRIMAAL BLUE CVBN

TRIMAL BLUE CVBN

TRISULFON BLUE FO

TRISULFON BLUE RW

VEGENTINE BLUE CSW

VISCO MILLING NAVY $R$

VONDACEL BLUE FF

VONDACEL BLUE HH

VONDACEL DARK BLUE CVB 


\section{SOURCES OF ADDITIONAL INFORMATION}

1. NATIONAL INSTITUTE FOR OCCUPATIONAL SAFETY AND HEALTH

Division of Standards Development and Technology Tranofer, Technical Information Branch

This office responds to inquiries from individuals and organizations on occupational safety and health iasues.

4676 Columbia Parkway

Cincinnati, Ohio 45226

\section{NIOSH Regional Offices}

Region I - Boston, Massachusetts: Connecticut, Maine, Massachusetts New Hampshire, Rhode IBland, Vermont

Region II - New York, New York:

New Jeraey, New York, Puerto Rico, Virgin Islands

Region III - Philadelphia, Pennsylvania: Delaware, Diatrict of Columbia, Maryland Pennsylvania, Virginia, West Virginia

Region IV - Atlanta, Georgia:

Alabama, Florida, Georgia, Rentucky, Mississippi, North Carolina, South Carolina, Tennessee
Regional Consultant, NIOSH DHHS, Region I

Government Center (JFR Fed. B1dg.)

Boston, Massachusetts 02203

Tel: $617 / 223-6668$

FTS : $223-6668$

Regiona1 Congultant, NIOSH DHHS, Region II - Fed. Building 26 Federal Plaza

New York, New York 10007

Te 1: $212 / 264-2485$

FTS : $264-2485$

Regional Consultant, NIOSH DHHS, Region III

P. 0 . Box 13716

Philadelphis, Pennsylvanis 19101

Tel: 215/596-6716

FTS : $\quad 596-6716$

Regional Consultant, NIOSH DHHS, Region IV, Div, of Preventive Health Services 101 Marietta Tower, Suite 1007 Atlanta, Georgia 30303

Te1: 404/221-2396

FTS : $\quad 242-2396$ 
Region V - Chicago, Illinois: Illinois, Indiana, Michigan, Minnesota, Ohio, Wiscons in

Region VI - Dallas, Texas: Arkansas, Louisiana, New Mexico, Oklahoma, Texas

Region VII - Kansas City, Missouri: Iowa, Ransas, Missouri, Nebraska

Region VIII - Denver, Colorado: Colorado, Montana, Utah, Wyoming, North Dakota, South Dakota

Region IX - San Francisco, California: Arizona, California, Hawai, Nevada, Guam

Region X - Seattle, Washington: Alaska, Idaho, Oregon, Washington
Regional Consultant, NIOSH

DHHS, Region $V$

300 South Wacker Drive, 33rd Floor Chicago, Illinois 60606

Tel: $312 / 886-3881$

FTS: $886-3881$

Regional Consultant, NIOSH

DHHS, Region VI

1200 Main Tower B1dg., Rm. 1700-A

Dallas, Texas 75202

Tel: $214 / 767-3916$

FTS : $\quad 729-3916$

Regional Consultant, NIOSH

DHHS, Region VII

601 East I2th Street

Kansas City, Missouri 64106

Tel: $816 / 374-5332$

FTS : 758-5332

Regional Consultant, NIOSH DHHS/PHS/PREVENTION-Region VIII

Denver, Colorado 80294

Te1: $303 / 837-3979$

FTS : $\quad 327-3979$

Regional Consultant, NIOSH DHHS, Region IX

50 United Nations Plaza San Francisco, California 94102

Te1: $415 / 556-3781$

FTS : $\quad 556-3781$

Regional Consultant, NIOSH

DHHS, Region $\mathrm{X}$

1321 Second Avenue (Arcade Bldg.)

Seattle, Washington 98101

Tel: 206/442-0530

FTS: $399-0530$

2. OCCUPATIONAL SAFETY AND HEALTH ADMINISTRATION, U.S. DEPARTMENT OF LABOR

Refer to the white pages of the telephone directory under "U.S. Department of Labor, Occupational Safety and Health Administration." 
3. DYES ENVIRONMENTAL AND TOXICOLOGY ORGANIZATION

This is a trade organization of dye manufacturers involved with health effects of commercial dyes.

DETO

1075 Central Park Avenue

Scarbdale, New York 10583

4. AMERICAN ASSOCIATION OF TEXTILE COLORISTS AND CHEMISTS

AATCC

P.O. Box 12215

Research Triangle Park, North Carolina 27709

In addition to publishing a periodical, this organization also publishes the Colour Index, a specialized multi-volume reference work that may be useful in identifying chemical dye components. This reference is most often found in reference collections of research libraries. Persons seeking to identify dye chemicals who do not have access to the Index can obtain assistance from NIOSH at the address given above for its Technical Information Branch.

5. AMALGAMATED CLOTHING AND TEXTILE WORKERS UNION

ACTWU

Occupational Safety and Health Department

15 Union Square

New York, New York 10003

6. FOOD AND BEVERAGES TRADES COUNCIL, AFL-CIO (leather dyeing)

Food and Beverages Trades Council, AFL-CIO

Health and Safety Program

815 16th Street, N.W.

Washington, D.C. 20006

7. UNITED PAPERWORKERS INTERNATIONAL UNION

UPIU

Department of Health and Safety

P.0. Box 1475

Nashville, Tennessee 37202 
8. OIL, CHEMICAL, AND ATOMIC WORKERS INTERNATIONAL UNION

OCAW

Health and Safety Department

P.0. Box 2812

Denver, Colorado 80201

9. INTERNATIONAL CHEMICAL WORRERS UNION

ICWU

Health and Safety Department

1655 West Market Street

Akron, Ohio 44313

10. CENTER FOR OCCUPATIONAI hazARDS (Art Hazards Project)

Center for Occupational Hazards

5 Beekman Street

New York, New York 10038 